\title{
Gerald Parolly
}

\section{The serpentine vegetation of Sandras Dağı revisited - Phytosociological studies on high-mountain plant communities of the South Anatolian Taurus Mountains, 4}

\begin{abstract}
Parolly, G.: The serpentine vegetation of Sandras Dağ ies on high-mountain plant communities of the South Anatolian Taurus Mountains, 4. Bocconea 29: 203-244. 2021 - ISSN: 1120-4060 printed, 2280-3882 online.

The serpentine vegetation of Sandras Dağı revisited. Phytosociological studies on high-mountain plant communities of the South Anatolian Taurus Mountains, 4. - The present paper deals with the high-mountain vegetation of Sandras Dağı, a fairly isolated main range in the SW Anatolian Taurus, Turkey, which is largely composed of peridotite rock and stands out for its rich endemic flora. Critically reviewing the phytosociological accounts on this topic, it proposes a classification scheme for the serpentinophytic vegetation in a wider sense. Three associations are described as new to science. While the Muscari sandrasici-Polygonetum karacae (meltwater and snow-bed community) fits in spite of its many local serpentinophytes into the Thlaspion papillosi alliance (Trifolio-Polygonetalia), the zonal mesophytic to xerophytic vegetation could hitherto not be classified satisfactorily. As a solution, the serpentinophytic Thuryion capitatae (Astragalo-Brometalia) of the Cilician Taurus is expanded in geographical and diagnostic respects, to accommodate also the stands as far West as Sandras Dağı. Here, they can be grouped into a Genistetum sandrasicae and an Odontarrheno masmenaeae-Ebenetum pisidicae. All communities are characterised by means of life form spectra, chorotype spectra and dispersal biological spectra. The only two available serpentinophytic Astragalo-Brometalia syntaxa from Turkey, including the name Thuryion capitatae, are validated. In addition, two suballiances are suggested that consider the floristic contrast between the western and eastern parts of the Taurus range.
\end{abstract}

Key words: Astragalo-Brometalia, biospectra, chorotypes, dispersal, ecology, oroxerophytic vegetation, phytosociology, serpentine, snow-beds, SW Anatolia, syntaxa, Taurus System.

\section{Introduction}

This is the continuation of long-interrupted series of papers dealing with the highmountain vegetation and flora of the Taurus Mts. in Anatolia, Turkey (Parolly 1998; Hein \& al. 1998; Kürschner \& al. 1999; Parolly 2004; Eren \& al. 2004). I am pleased to dedicate this part of the study to Prof. Dr George Nakhutsrishvili on the occasion of his $85^{\text {th }}$ birthday. Add multos annos, Gia! 
The serpentine massif of Sandras Dağ 1 is in botanical respects one of the classical peaks in Anatolia (Boissier 1867-1884; Davis 1949, 1955; Davis 1965-1985; Davis \& al. 1988; Güner \& al. 2000). Its many local endemics have attracted the attention of numerous collectors. The mountain range is generally considered to be well known (Hartvig \& Strid 1987; Karlén 1987; Özhatay 1981, 1987, 1993; Özhatay \& al. 2003), but there are also some more recent additions to its endemic flora (Parolly \& Scholz 2004; Varol 2005).

As far as the high-mountain vegetation is concerned, Sandras Dağı has received a fairly comprehensive treatment in Quézel's fundamental "Contribution à l'étude phytosociologique du massif du Taurus" (1973), in which not less than eight communities, classified into five different major syntaxa and formations, are dealt with. These are:

- three edaphically differentiated Astragalo-Brometea Quézel 1973 communities (dwarf-shrub and thorn-cushion communities), included in the otherwise completely basiphytic Tanacetion praeteriti Quézel 1973, viz. (1) the "groupement à Convolvulus cochlearis et Chamaecytisus eriocarpus" on "rocailles compactes de faible inclinaison"; (2) the "groupement à Alyssum propinquum et Sesleria phleoides" on "èboulis fixés, crêtes que sous-couvert forestier clairsemé" and (3) the "groupement à Ebenus pisidica et Plantago carinata" on "cuvettes terreuses";

- a "doline" vegetation on humid soil (Trifolio-Polygonalia Quézel 1973, Bolanthion frankenioidis Quézel 1973, Association à Plantago carinata et Poa persica var. alpina Quézel 1973);

- a rock community, i.e. the "groupement à Viola sandrasea et Rosularia serpentinicum” (Silenetalia odontopetalae Quézel 1973);

- a fragmentary flush community (only three 3 species were recorded in the single relevé), which cannot be classified phytosociologically, although Quézel attached it preliminary to his groupement à Blysmus compressus et Rorippa aurea;

$\checkmark$ and a fragmentarily known scree plant community not supported by particular relevés.

All but one unit, the Association à Plantago carinata et Poa persica var. alpina, which is widespread in the western Taurus, were considered to be restricted to Sandras Dağ1 and some other neighbouring ophiolitic summits. Quézel's results (1973) were widely confirmed (but without additional relevés) and accepted by Öztürk \& al. (1991) and Gemici \& al. (1994) in their synthetic study on the highmountain flora and vegetation of $\mathrm{W}$ and $\mathrm{S}$ Anatolia. Although unpublished and therefore irrelevant in nomenclatural respects (it includes many invalid new names), the latter study is (or was) circulated with considerable influence among the Turkish scientific community.

In front of such a research history, nobody would realistically expect that something worth to be communicated about the high-mountain vegetation of Sandras Dağ could be left, some minor syntaxonomic or nomenclatural adjustments excepted. However, the contrary was the case. In 1999, while doing extentive fieldwork on the high-mountain vegetation of the Taurus range, I realised that the situation encountered in the field did at best in part match the published results. 
The present paper will introduce a new hygrophytic association in showing the independent status of the local unit from the Association à Plantago carinata et Poa persica var. alpina and the Muscari bourgaei-Ornithogaletum brevipedicellati Quézel 1973. This new syntaxon is, due to the many serpentinophytes, the most distinct TrifolioPolygonetalia community hitherto known. Moreover, two of three of Quézel's informal Astragalo-Brometalia "groupements" are lumped into one here formally described Genistetum sandrasicae, while a not yet observed association occurring at windswept places, is added. In this context it must be noted that Quézel's plots have a standard size of $100 \mathrm{~m}^{2}$. Experience with the vegetation in the Taurus Mts. has shown this plot size to often end up in site-ecologically and floristically heterogeneous relevés (Parolly 1998; Hein \& al. 1998; Kürschner \& al. 1998; Parolly 2004).

In an earlier paper, on the occasion of reviewing the high-mountain vegetation of Anatolia (Parolly 2004), I have made some preview suggestions concerning a revised syntaxonomy of the serpentine vegetation of the western Taurus range. Due to the limitation of space, these necessary changes could not be substantiated by relevés. I take here the opportunity to make up for it and to support the proposed concepts by an adequate documentation. As a conclusion, a greatly modified classification of the asylvatic vegetation of Sandras Dağ 1 can be presented, which has more than local value. For Anatolia, it approaches for the first time consistent solutions how to incorporate serpentinophytic stands into a system of basiphytic vegetation units that at the same strongly reflect phytogeographic patterns.

\section{Study area}

Sandras Dağı, situated ca. 20 km N of Köyceğiz (Figs. 1-2), culminates in Çicekbaba Tepesi at $2294 \mathrm{~m}$ under $37^{\circ} 05^{\prime} 15.76 \mathrm{~N}$ and $28^{\circ} 50^{\prime} 21.88 \mathrm{E}$ (Figs. 3-4). Geologically the mountain range is completely composed of ultramafic, softly weathering rocks of the Peridotite nappe (Brunn \& al. 1971; Şenel 1991). They crop out of the surrounding Lycian Nappes that comprise mostly limestone units. In higher elevations of Sandras Dağı, peridotites prevail, which contain orthopyroxenes and magnesian olivines. The peridotites are cut by pyroxenites and dolerite dykes. They develop into acidic soils $(\mathrm{pH}$ values 4.5-5.5) with very low percentages of $\mathrm{CaCO}_{3}(1-2 \%)$.

The forest-line is given by Quézel (1973) at $2100 \mathrm{~m}$, but extensive clearing has widely depressed it to 1600-1800 m (Fig. 3a). Rocky slopes and boulder-rich summit plateaux covered by Astragalo-Brometalia communities predominate, but there are also scattered small, flat areas and depressions with abundant finer soil, which support a particular type of herbaceous hygrophytic vegetation (snow-beds).

\section{Materials and Methods}

\section{Phytosociological sampling}

The present paper follows the conventions of the Braun-Blanquet approach (BraunBlanquet 1964), with the major modifications introduced since that time (Dierßen 1990; 


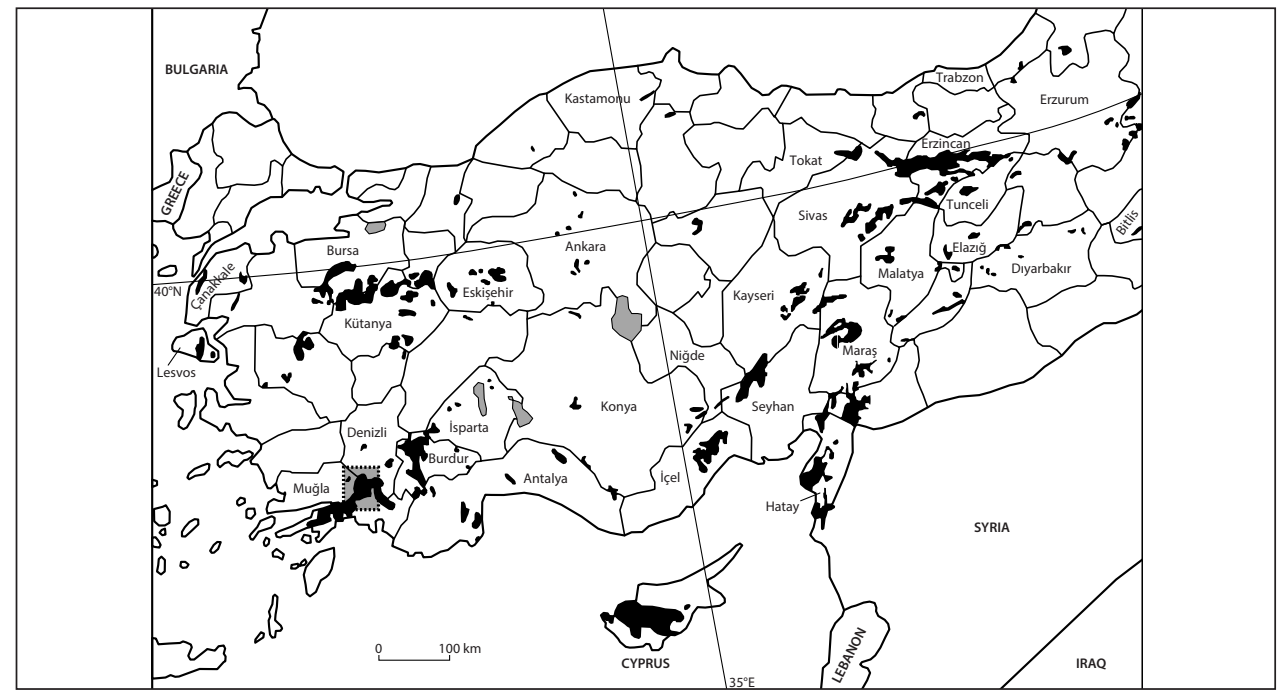

Fig. 1. Situation of the study area in SW Anatolia (approximately indicated by the dotted and highlighted quadrangle) and distribution of ultramafic rock (in black) in Turkey and adjacent regions (especially Cyprus). Grey: Lakes. - Based on a map by Reeves \& Adigüzel (2004, altered).

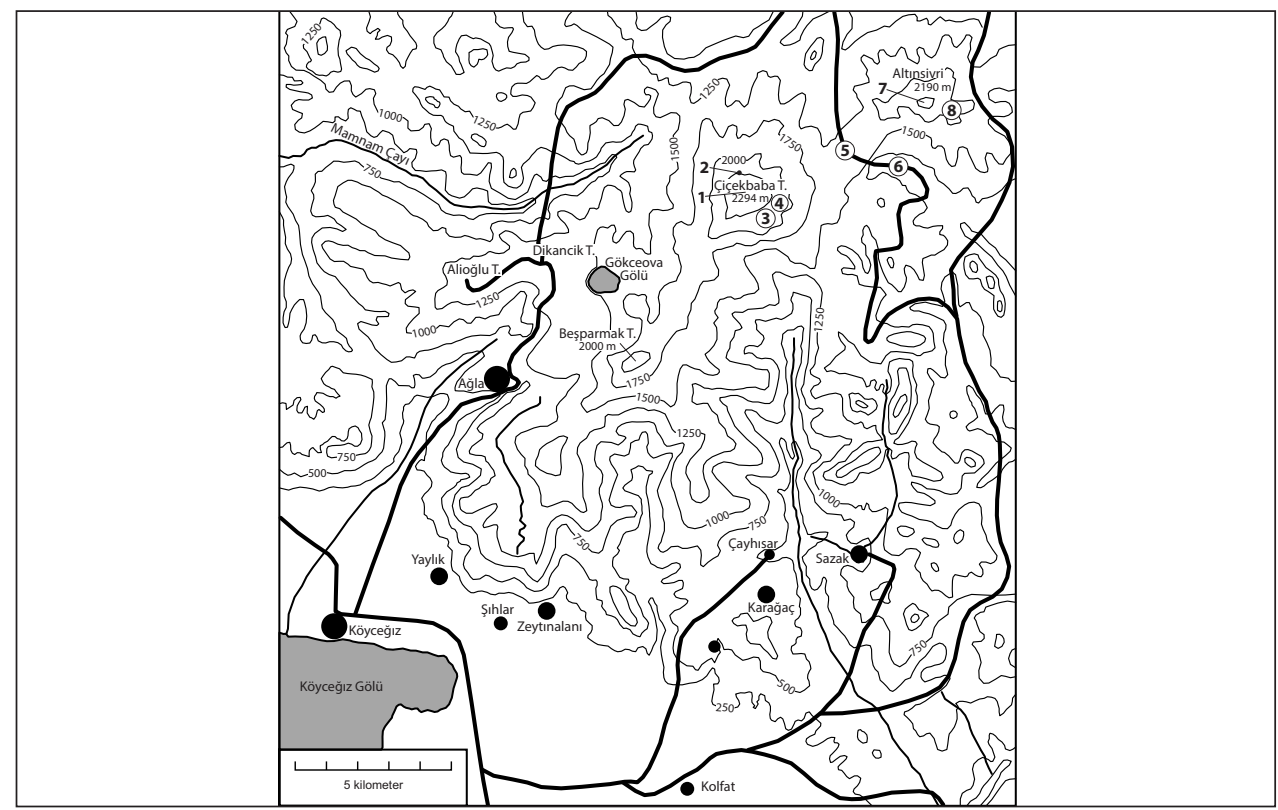

Fig. 2. Topographic map of the wider study area (Sandras Dağı range) and sampling localities (1-8). For more detailed place names, see Appendix 2. Note that the localities shown on the map have been numbered from left to right, while the localities and plots annotated in the appendix are chronologically arranged. Grey: Lakes; black dots: Villages and small settlements. - Based on a map by Özhatay (1993, altered). 


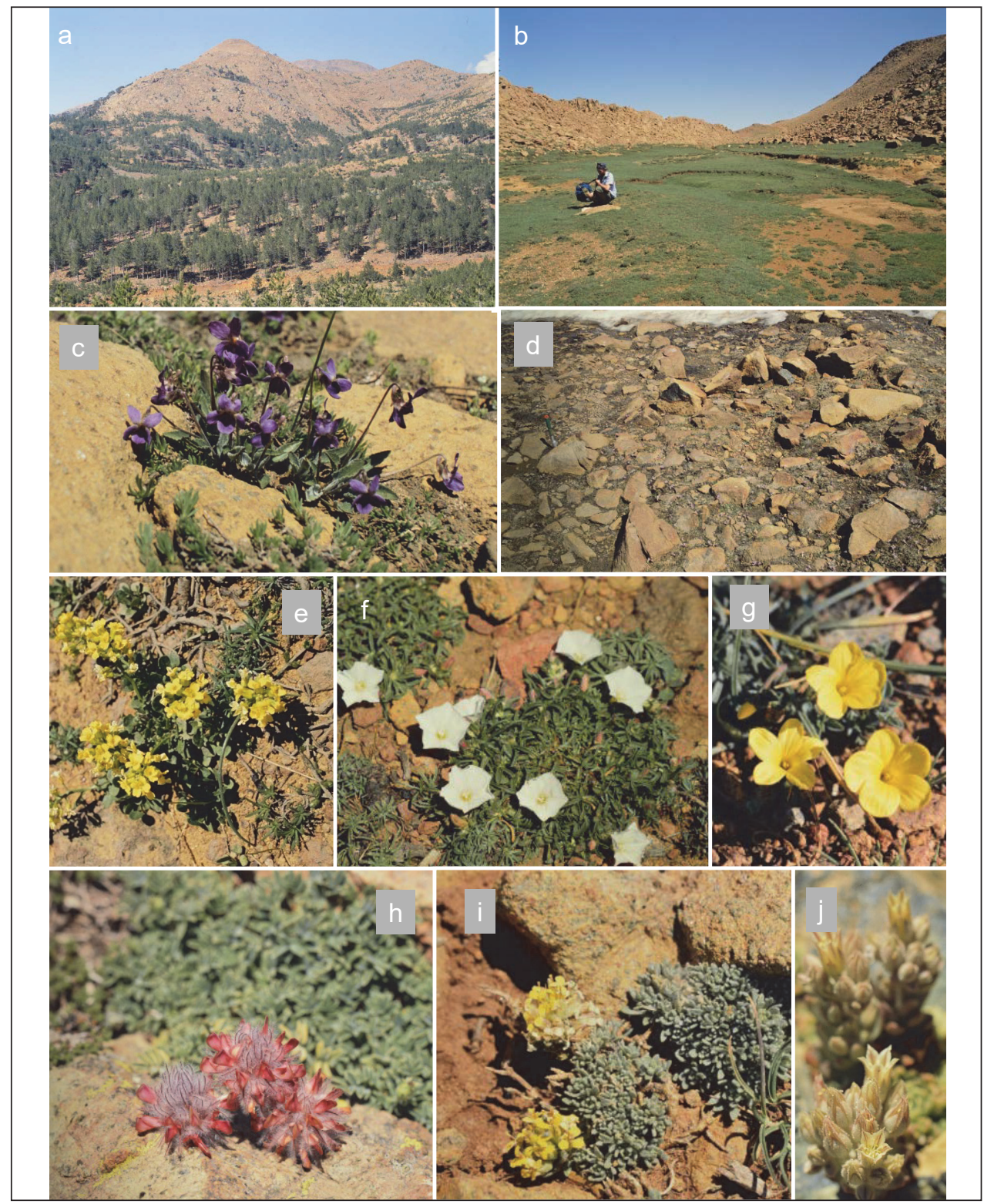

Fig. 3. Landscapes and habitats of Sandras Dağı. a) Main summit (Çiçekbaba Tepesi) with Pinus nigra var. caramanica forest and subalpine belt; b) dense snow-bed turf of the Muscari sandrasici-Polygonetum karacae association with abundant Plantago holosteum; c) Viola sandrasea subsp. sandrasea; d) stand of a meltwater community (Muscari sandrasici-Polygonetum karacae) with Barbarea brachycarpa subsp. anfractuosa, Colchicum figlalii, Scilla pleiophylla, Ranunculus heterorhizus and other geophytes; e - j) characteristic serpentine taxa of the Sandras Dağ range: e) Barbarea brachycarpa subsp. anfractuosa; f) Convolvulus libanoticus; g) Linum boissieri; h) Ebenus pisidica; i) Alyssum propinquum; j) Prometheum serpentinicum. 


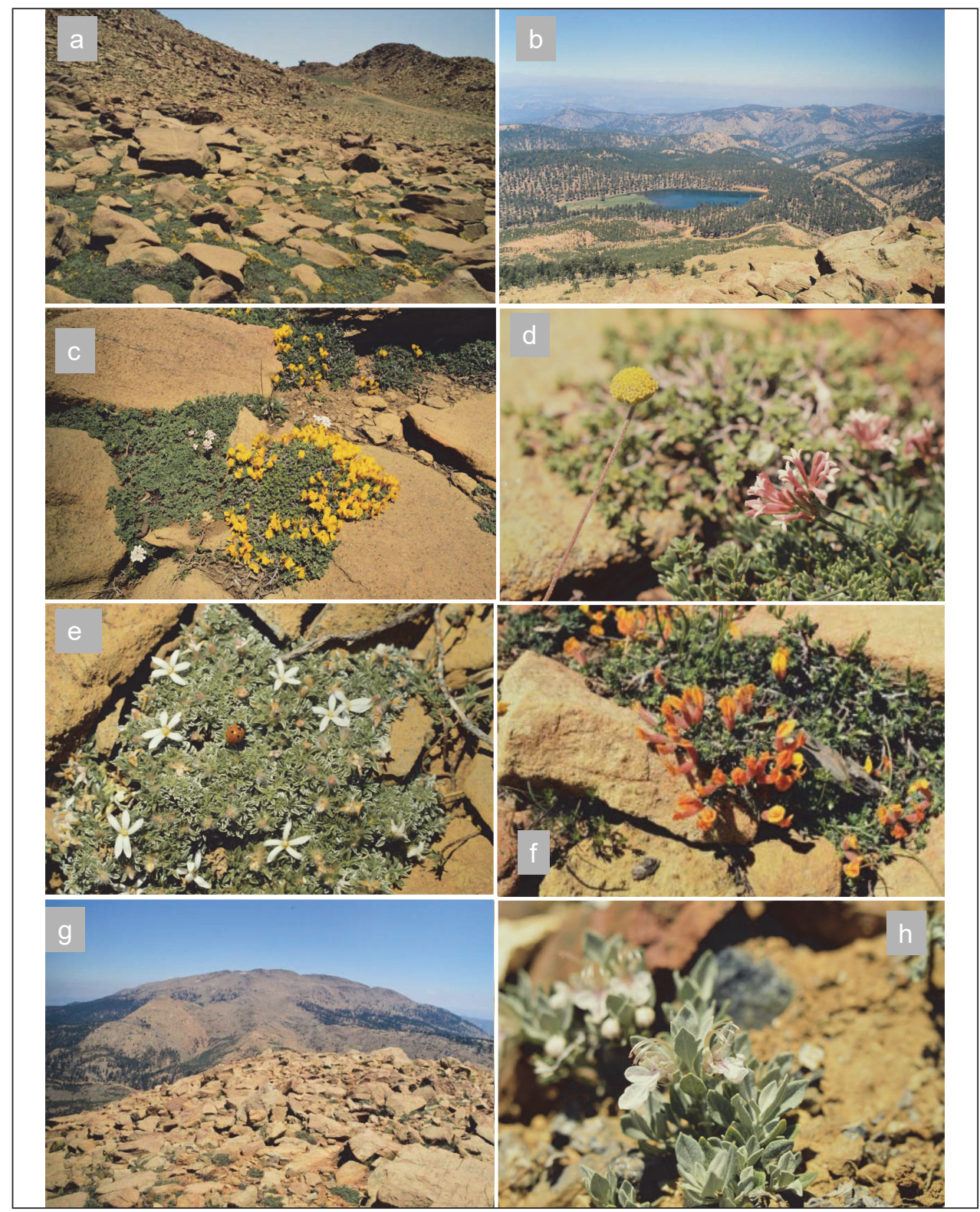

Fig. 4. Landscapes and habitats of Sandras Dağı. a) Typical site and appearance of a stand of the Genistetum sandrasicae; b) view from the main summit towards Gökceova Gölü (in the foreground: boulder scree supporting a stand of the Odontarrheno masmenaeae-Ebenetum pisidicae association); c) Aethionema speciosum subsp. compactum (white flowers) and Chamaecytisus pygmaeus (yellow) within Genistetum sandrasicae; d) Anthemis cretica and Asperula stricta subsp. monticola; e) Convolvulus compactus, an individual with an untypically deeply split corolla; f) Cytisopsis pseudocytisus subsp. reeseana; $\mathbf{g}$ ) typical site of the local dwarf-shrub vegetation (Genistetum sandrasicae) on the summit flat of Altınsivri facing Çiçekbaba Tepesi; h) Teucrium alyssifolium. 
Dierschke 1994). The combined valuation of the abundance and cover adopts the scale of Barkman \& al. (1964) with the modification that the " $2 \mathrm{~m}$ " value is replaced by " $1 \mathrm{~m}$ ".

The field-work was carried out in June 1999. A total of ca. 55 relevés have been established on Sandras Dağ 1 between 1700 and 2300 m. Omitting duplicate relevés, 35 of them entered the community tables (Tables 1-3). In addition, 13 selected relevés of Quézel (1973) are considered (Table 7). All sampling localities are indicated in Fig. 2 and listed with their locality numbers used in the headings of the community tables in Appendix 2.

\section{Composition of community tables; syntaxonomy}

The community tables (Tables 1-3) are not straighten out to display the most typical stands only. They sometimes also include, in order either to reflect syndynamical trends or transitions along ecological gradients, floristically heterogeneous, nevertheless very instructive relevés. Such relevés (e.g. relevé 20a, b) are set apart by dotted lines and were not or separately considered in the calculation of the biospectra.

Below the character species (CS) and differential species (DS) of the respected communities (associations and their subunits), the tables are horizontally arranged to exhibit syntaxonomic species groups with ecological and or zonal information, such as AstragaloBrometalia (xeric sites, oreal to subalpine), Trifolio-Polygonetalia (damp to chionophytic) and Drabo-Androsacetalia (wind-exposed, often lithophytic habitats). The treatment of the diagnostic taxa of the Astragalo-Brometalia and the Astragalo-Brometea (incl. TrifolioPolygonetalia) and related subunits are in accordance with Parolly (2004) and Eren \& al. (2004; see also Kürschner \& Parolly 2012).

The "Code of Phytosociological Nomenclature" (ICPN, Weber \& al. 2000) has been applied for all nomenclatural procedures involved.

Analyses of life forms, chorotypes and dispersal biology of the communities. Calculation of biospectra

For all communities studied, life form spectra (Table 4), chorotype spectra (Table 5) and dispersal biological spectra (Table 6) are given. Their calculation follows Reichelt \& Wilmanns (1973). The life form spectra and dispersal biological spectra are presented weighted, i.e. based on the mean percentage cover value (mpc-value) of the taxa within the communities. By contrast, chorotype spectra consider the species frequency in calculating an un-weighted group percentage (gp-value). Life form, chorotype and dispersal biological features of each species recorded within the communities of Sandras Dağ 1 are compiled in Appendix 1.

The phytogeographic elements were chiefly attributed according to the "Flora of Turkey and the East Aegean Islands" (Davis 1965-1985; Davis \& al. 1988; Güner \& al. 2000), the “Conspectus Florae Orientalis" (Heller \& Heyn 1986-1994; Zohary \& al. 1980, 1983), the "Exkursionsflora für Kreta" (Jahn \& Schönfelder 1995), the "Geobotanical Foundations of the Middle East" (Zohary 1973), as well as Kürschner (1982, 1984), Parolly (1995), Hein \& al. (1998), Kürschner \& al. (1998) and Eren \& al. (2004). 
The analysis of the life forms (Raunkiaer 1934; Ellenberg \& Müller-Dombois 1967; for distinguished types see Table 4 and Frey \& Lösch 2004) is, as in dispersal biology, largely related to the own field observations backed by voucher specimens and only in the second line reference-based. Most attributions of life forms accord with Jahn \& Schönfelder (1995). In cases in which species develop under the influence of their environment two (or three) deviating life forms, the mpc-value were split, if they are found with \pm the same frequency. If one life form of a taxon is less frequent and significant within a syntaxon than the other(s), it is given in brackets and not considered in the calculation at all. The same procedure was followed in the dispersal biology.

Some patterns of dispersal biology were analysed by judging the dispersal mechanism of a taxon from its diaspore morphology (construction type). This theoretical approach was rightly criticised by van der Pijl (1969: 2), but accepted as starting point that cannot be dismissed. Fortunately, the structural aspects can often be supplemented by a wide range of own actual field observations of dispersal (indicated by an exclamation mark in Appendix 1) and references (e.g., Müller-Schneider 1983, 1986, especially for Poaceae; indicated by an "L" for literature).

\section{Taxonomy and treatment of critical taxa}

Since Quézel (1973) had published his "Contribution", many plant groups were revised for the then appearing "Flora of Turkey and the East Aegean Islands" (Davis 1965-1985; Davis \& al. 1988; Güner \& al. 2000) and even later new species were discovered from Sandras Dağı (summarised in Güner \& al. 2000, see also Varol 2005). This makes taxonomic and nomenclatural adjustments inevitable.

The accepted names follow "Flora of Turkey", updated by the "Türkiye Bitkileri Listesi" (Güner 2012), "The Euro+Med PlantBase" (http://ww2.bgbm.org/EuroPlusMed/query.asp), "Flora Hellenica" (Strid \& Kit Tan 1997, 2002), Böhling \& Scholz (2003), Bolliger (1996), Eren \& al. (2004) and Parolly \& Eren (2006, 2007). Comments in the text and the synoptic table (Table 7) harmonise the taxonomy and nomenclature between Quézel's (1973) and the present account. These remarks are given in brackets and include: syn. (= synonym); tax. (= taxon added to Flora of Turkey later than 1973) and rev. (= quite likely a misidentification by Quézel).

A proper interpretation of the names was especially needed, when the taxa were syntaxonomically significant or eponymous, such as those of the "groupement à Convolvulus cochlearis et Chamaecytisus eriocarpus", the "groupement à Alyssum propinquum et Sesleria phleoides", the "groupement à Ebenus pisidica et Plantago carinata" and the "groupement à Viola sandrasea et Rosularia serpentinicum". While Convolvulus cochlearis, Plantago carinata and Rosularia serpentinicum are easily detected as synonyms of C. compactus, P. holosteum and Prometheum serpentinicum, respectively, "Chamaecytisus eriocarpus" turned out to be a mixture of Ch. pygmaeus and Cytisopsis pseudocytisus subsp. reeseana, and Sesleria phleoides at all places studied to be S. alba. In the case of Festuca ovina (s. 1.), two species of the group were recorded by the relevés, i.e. F. elwendiana and F. valesiaca (both were indicated in square brackets in Table 7). Other critical records by Quézel (1973) and necessary changes are discussed, below, in the description of the communities. Appendix 1 lists all taxa recorded. 


\section{Results and Discussion}

\section{Phytosociology: Community descriptions}

Muscari sandrasici-Polygonetum karacae Parolly, ass. nov.: Serpentinophytic meltwater community stands and snow-bed turf of the Western Taurus (Table 1; Fig. 3b-e)

Holotypus: Table 1, relevé 7. - CS: Barbarea brachycarpa subsp. anfractuosa, Colchicum figlalii, Muscari sandrasicum, Ranunculus heterorhizus. DS (loc.): Polygonum karacae.

Site conditions. - In sharp contrast to limestone, where the water trickles quickly away, serpentine and associated rocks provide geological substrates which support extensive stands of chionophytic vegetation. On Sandras Dağı, the many, often local serpentinophytes differentiate a floristically very particular vegetation unit, which is described here as a new association. This Muscari sandrasici-Polygonetum karacae colonises gently slopping to horizontally stretching valley bottoms, gravely or stony flats and the flat boulder-fields of the summit region. At such places, it forms a fairly dense, bluish-green to dark green turf (Fig. 3b), in early mountain summer spotted by arrays of flowers. Hartvig \& Strid (1987) refer to such stands as "snow-bed meadows". More rarely, and often only fragmentarily developed, the Muscari sandrasici-Polygonetum karacae occurs as a geophyte-dominated meltwater community (Fig. 3d) along the meltwater runnels in various inclinations.

Stands of the associations are preferably found in elevations between 1900 and $2250 \mathrm{~m}$, but there are some remarkable outpost lower down $(1650 \mathrm{~m})$ on the depressions of a gravely plain. On 20-21 June 1999, large snowfields were abundant especially in N- and Wexposures and a few snow-patches in E-facing slopes, all supporting strongly flowing meltwater runnels.

Structure and floristical composition. - In physiognomic respects (see Table 4), the Muscari sandrasici-Polygonetum karacae forms either the afore mentioned open, geophyte-dominated meltwater community (along steep and rocky meltwater runnels [Fig. 3d and Table 1a: relevés 20a, 20b] or in shallow depressions below late snow snow-patches (Table 1b: relevés 7-9) or snow-bed turf (Fig. 3b and Table 1b: relevés 10-13, Table 1c: relevés 21-23). The overall impression of stands of the association is that of a carpet-turf dominated by a few, low-growing, rosulate hemicryptophytes and pulvinate chamaephytes (total mpc-value 58.4\%), seven geophytic species (19\%), a few suffruticose chamaephytes (9.2\%, especially due to Polygonum karacae) and caespitose hemicryptophytes $(6.9 \%)$. Plantago holosteum (P. carinata) is structurally the most significant element.

Because Plantago holosteum occurs both as large, flat and compact cushion and as more loosely trailing rosette plant, its mpc-value of 58.2\% was split into these two life categories (Ch pulv and $\mathrm{H}$ ros). Tragacanthic species are, as it is usual for this vegetation order and for serpentine soils in the Taurus range, seldom and here represented only by Astragalus angustifolius var. violaceus.

The meltwater vegetation type covers only $5-30 \%$ of the surface and the plants are scattered among stones and block debris (proportion of rock and stone 35-80\%). In steep and 
rocky meltwater runnels close to the snow-fields, the species inventory is, at least in early mountain summer, very fragmentary and consists nearly exclusively of the most chionophytic species. In particular Colchicum figlalii, Scilla pleiophylla, Ranunculus heterorhizus (Fig. 3d), and more rarely Barbarea brachycarpa subsp. anfractuosa (Fig. 3e), are able to penetrate through the snow-cover and to flower in the midst of the running meltwater, which flows strongest in the afternoon. The two fragmentary relevés 26-27 have not been further considered in the calculation of the biospectra.

By contrast, the turf impression is much more real in the extensive snow-beds (Fig. $3 \mathrm{~b}$ ) with their total vegetation cover ranging normally between 60 and $80 \%$ and with lower proportions of stones at the surface. Plantago holosteum reaches here is highest combined abundance-coverage values. In addition, the chamaephytic companions and the Thuryion capitatae species are physically much better developed than in the meltwater community stands.

The character species of the Muscari sandrasici-Polygonetum karacae include with Barbarea brachycarpa subsp. anfractuosa, Colchicum figlalii, Muscari sandrasicum and Ranunculus heterorhizus mostly local (Sandras Dağı and neighbouring summits) or at least SW Anatolian endemics (Ranunculus heterorhizus). All but the latter species appear to be exclusive serpentinophytes, while Ranunculus heterorhizus also dwells on other non-limestone substrates. As often in the hygrophytic Trifolio-Polygonetalia vegetation, the character species are centred in that unit, but they may occasionally even join the early spring flora of open mountain forests.

Barbarea brachycarpa (as B. minor and its varieties) has variously been recorded as major character species associated with the Trifolio-Polygonetalia vegetation (Kürschner \& al. 1998; Quézel 1973; Parolly 2004), before the B. brachycarpa aggregate was revised and phytosociologically re-evaluated by Parolly \& Eren (2007). Subsp. anfractuosa (Fig. 3e) is one of the two serpentinophytes within this geographically and edaphically well differentiated species. It marks places with a long-lasting snow-cover and is hitherto only known from Sandras Dağ Barbarea brachycarpa subsp. anfractuosa and is the least chionophytic one among the diagnostic species. Colchicum figlalii (as Merendera figlalii) is a recent addition to the serpentine flora of Sandras Dağı and Turkey (Varol 2005; Parolly \& Eren 2007). Unlike as indicated in its protologue, it is, at the right time and right place, a quite abundant appearance in the summit region of that mountain range.

In addition to the character species of the association, the Muscari sandrasiciPolygonetum karacae is differentiated against all other Trifolio-Polygonetalia vegetation units by a group of species which circumscribe the serpentinophytic Thuryion capitatae s. 1. Many basiphytic Trifolio-Polygonetalia vegetation units are marked by transgressive character species and differential species of the Tanacetion praeteriti Quézel 1973 and Agropyro-Stachydion alliances Quézel 1973 (all. Astragalo-Brometalia). The most remarkable Astragalo-Brometea species among them is Polygonum karacae. It is a prostrate shrublet first described from Sandras Dağ1, but later recorded from several others, much dryer places in the Western and Pisidian and Isaurian Taurus (Eren \& al. 2004). It is locally confined to the damp wing of the Astragalo-Brometea vegetation.

The set of character species and differential species is equally well represented at ordinal level. Ornithogalum alpigenum is ranked here for the first time among this group. The 
Table 1. The Muscari sandrasici-Polygonetum karacae ass. nov. (Thlaspion papillosi, TrifolioPolygonetalia) on Sandras Dağı. 1a-b) typical variant (1a relevés from steep and rocky meltwater runnels); 1c) Euphorbia erythrodon variant.

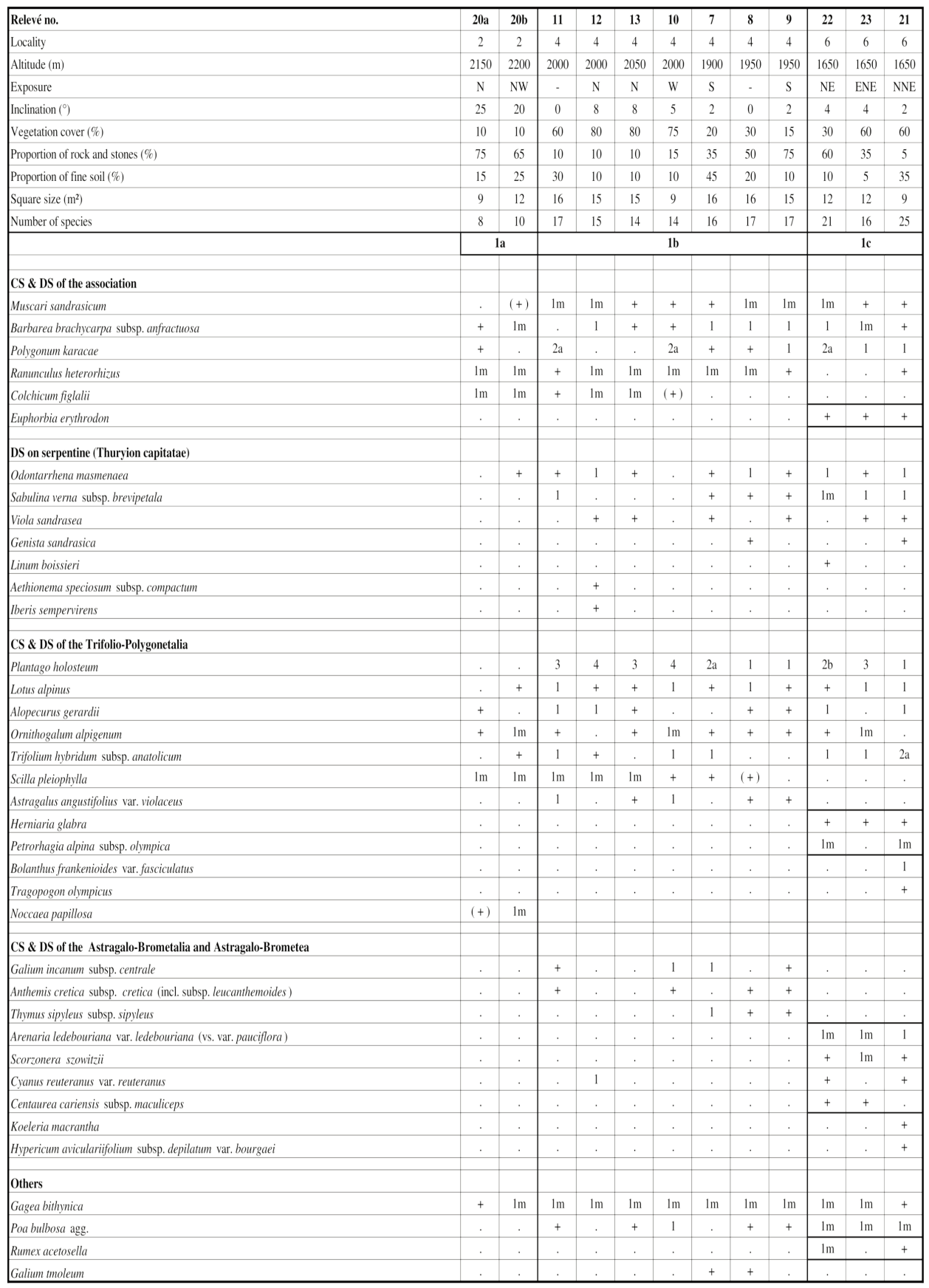


occurrence of Scilla pleiophylla (with its Lycian-Pisidian-Isaurian distribution pattern) as well as the observations of Noccaea papillosa outside the relevés links the Muscari sandrasici-Polygonetum karacae to the Thlaspion papillosi Kürschner, Parolly and Raab-Straube 1998 or the Bolanthion frankenioidis Quézel 1973, respectively. Gagea bithynica is a constant companion, which functions as fine-soil indicator.

Distribution. - The Muscari sandrasici-Polygonetum karacae is presently only recorded from its type locality. Its narrow endemics make a wider range extension outside the Sandras Dağ 1 Peridotite Nappe very unlikely; this all the more since the author has studied the vegetation of the very few other mountains in the Taurus range (see Parolly 2004; Eren \& al. 2004), where ophiolites or peridotites crop out in high montane or subalpine elevations.

Subdivision, community differentiation. - The montane altitudinal form of the Muscari sandrasici-Polygonetum karacae (Table 1c) is distinguished by the substrate-vag Anatolian endemic Euphorbia erythrodon, the Trifolio-Polygonetalia species Herniaria glabra, Petrorhagia alpina subsp. olympica and Bolanthus frankenioides var. fasciculatus, as well as a number of transgressive Astragalo-Brometalia species. Due to the shorter period of snow-cover and no additional meltwater supply, the sites of the Euphorbia erythrodon variant are mesic. The most chionophytic species of the association are consequently lacking and replaced by an enhanced number of more robust taxa. Due to the stronger grazing pressure, ruderals (Rumex acetosella) and other species adapted to such conditions join the unit (Herniaria glabra, Cyanus reuteranus, Scorzonera szowitzii). This (low) altitudinal form is thus at the same time the trampled turf variant of the Muscari sandrasici-Polygonetum karacae. Its distinctness and transitional position towards the mesophytic to xerophytic Thuryion capitatae communities is also evidenced by the modified dispersal biological spectrum (see below).

Syntaxonomic comparison and classification. - The many serpentinophytes as well as the occurrence of Gagea bithynica, Ornithogalum alpigenum and Anthemis cretica s. str. (Fig. 4d) make the Muscari sandrasici-Polygonetum karacae a distinct and easy-to-identify new association. It is the substrate-vicarious, serpentinophytic unit of the Muscari bourgaeiOrnithogaletum brevipedicellati Quézel 1973 (see 5. Concluding remarks), but it has due to the abundance of Plantago holosteum and Alopecurus gerardii also much affinities with Quézel's “Association à Plantago carinata et Poa persica var. alpina”. The Muscari sandrasici-Polygonetum karacae is preliminary included in the Thlaspion papillosi alliance, because it seems to be premature to establish a particular serpentinophytic (sub)unit, as far as the serpentinophytic vegetation of S Anatolia has not been studied more comprehensively.

Genistetum sandrasicae Parolly, ass. nov.: Serpentinophytic dwarf-shrub community of the Western Taurus (Table 2; Fig. 4a, c, g)

Holotypus: Table 2, relevé 6. - CS: Aethionema speciosum subsp. compactum, Genista sandrasica, Prometheum serpentinicum, Verbascum cariense, Viola sandrasea subsp. san- 
drasea. DS (loc.): Chamaecytisus pygmaeus, Cytisopsis pseudocytisus subsp. reeseana.

Incl.: Groupement à Ebenus pisidica et Plantago carinata (Quézel 1973), groupement à Convolvulus cochlearis et Chamaecytisus eriocarpus (Quézel 1973) p. p.

Site conditions. - The Genistetum sandrasicae is, from ca. $1800 \mathrm{~m}$ upwards, the prevailing dwarf-shrub and thorn-cushion community of the high montane and subalpine belt of Sandras Dağı. It holds among the tree-less vegetation units the most extensive stands and occupies in various aspects all suitable \pm mesic, moderately xeric or moderately hygric sites of the summit areas. The site amplitude of the community is considerable; it can be found both at flat places and in the steepest rocky slopes (to an angle of slope of $40^{\circ}$ ). It only recedes in the most xeric, scree-rich and wind-swept S- and W-exposures along the ridges of the summit region, leaving space for the establishment of the xerophytic Odontarrheno masmenaeae-Ebenetum pisidicae. With sufficient water supply and soilcover (usually at least $15-20 \mathrm{~cm}$ soil above bedrock), the Genistetum sandrasicae also occurs in wind-exposed sites to form the vegetation of the rocky summit flats (Gipfelfluren, Fig. 4g) as it is the situation on Altınsivri. In addition, the Genistetum sandrasicae covers large doline-like depressions, sometimes with snow-fields, where it gradually merges into the Muscari sandrasici-Polygonetum karacae. During the summer months, the stands of the Genistetum sandrasicae suffer increasingly from the summer drought (obs. August 2006); this also explains the principally xerophytic appearance of the community which otherwise clearly prefers mesic sites.

In lower elevations, the Genistetum sandrasicae may well replace cleared and strongly browsed Pinus nigra var. caramanica forests. Very similar stands establish themselves on small to mid-sized clearings in the forest. Fragments of the Genistetum form here together with forest initial species the understory under 1-4 m tall pine young growth. Such transitional stands (syndynamical stages) are very often dominated by large clones of the 50-100 $\mathrm{cm}$ tall and showy serpentinophytic Centaurea ensiformis P. H. Davis. They were not included in the present study.

Structure and floristical composition. - The Genistetum sandrasicae is a typical espalier shrub and shrublet community, where creeping chamaephytes hold an amazing 48\% mpc-value (see Table 4). Three Fabaceae species (Chamaecytisus pygmaeus, Cytisopsis pseudocytisus subsp. reeseana, Genista sandrasica) are in particular responsible for this high value, and together with many others, for the predominance of the yellow floral aspect. Another fifth of the life form spectrum is made up by xerophytic half-shrubs, so that the Genistetum sandrasicae meets well the physiognomic expectations for an Astragalo-Brometalia unit in being dominated by chamaephytes. Tragacanthic species are, characteristically deviating from the situation on limestone, weakly represented (here \pm singly by Acantholimon ulicinum var. purpurascens) and structurally fairly insignificant. Only the most xerophytic variant of the association (variant of Teucrium alyssifolium, see below and Table 2b) might be termed as open thorn-cushion community on scree.

Stands of the Genistetum sandrasicae usually cover more than $50 \%$ of the ground, with various proportions of rock and visible soil at the surface. It is a bi-layered community; the espalier shrubs seldom attain heights of more than $10 \mathrm{~cm}$. The thorn-cushions, too, remain fairly small and low. They are overtopped by $20-40 \mathrm{~cm}$ tall graminoids, some taller 
Table 2. The Genistetum sandrasicae ass. nov. (Thuryion capitatae, Astragalo-Brometalia) on Sandras Dağı. 2a) typical variant; 2b) Teucrium alyssifolium variant.

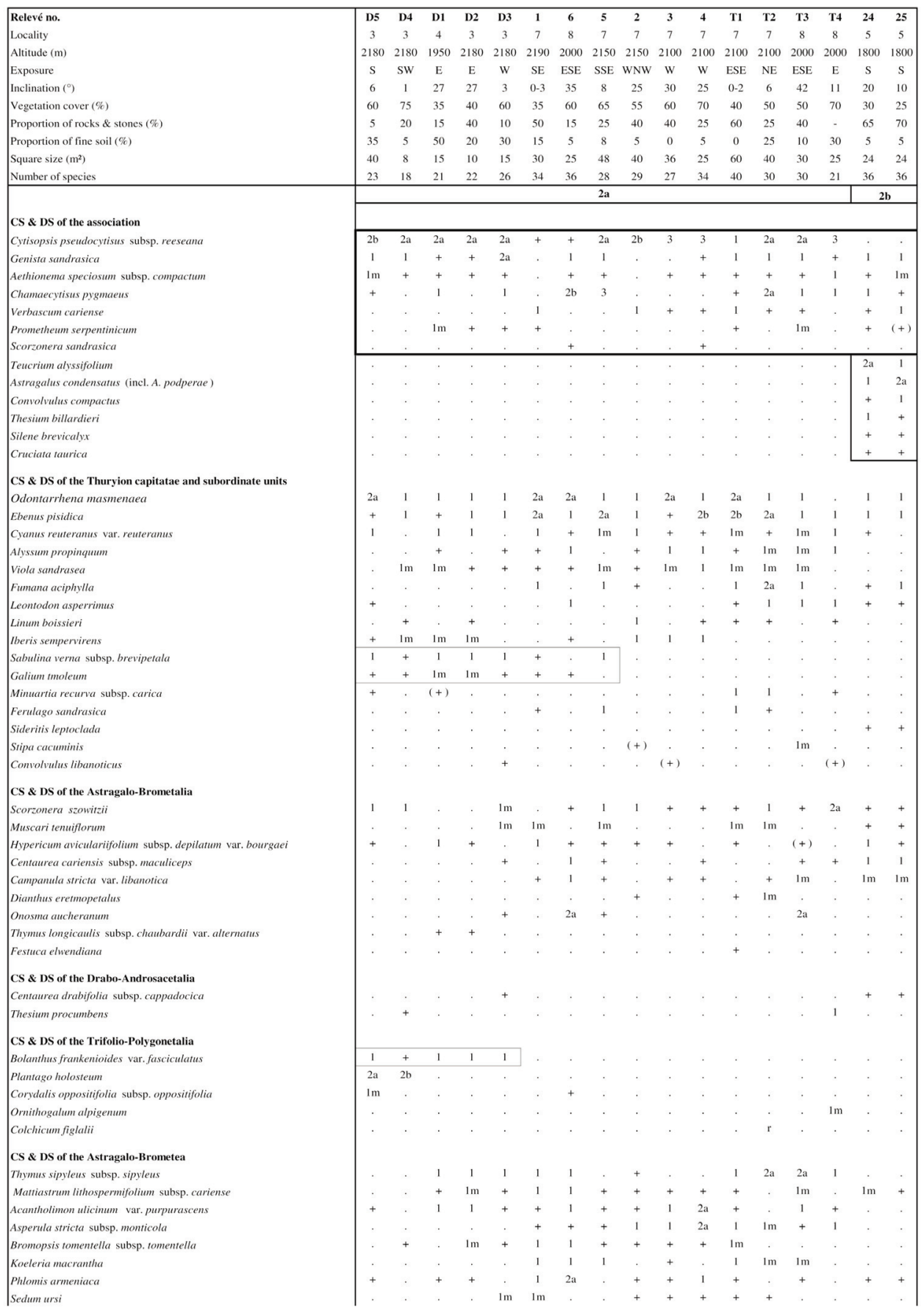


Table 2. continued.

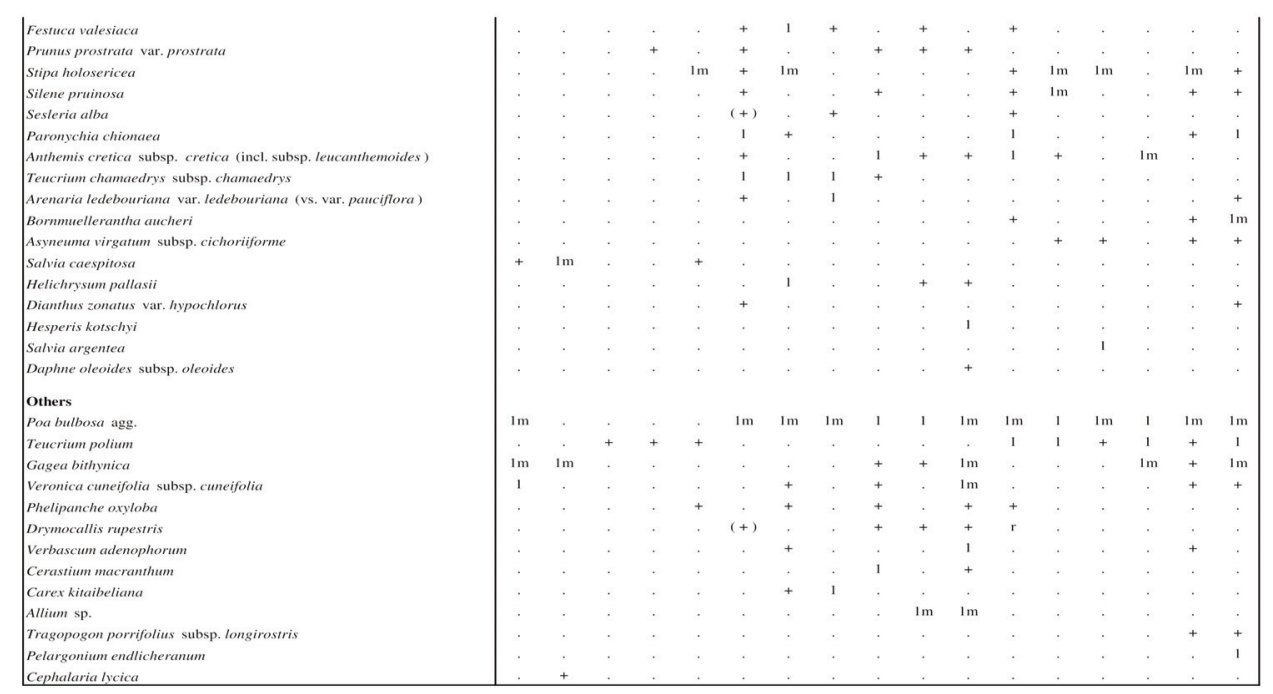

hemicryptophytes (e.g., Ferulago sandrasica, Mattiastrum lithospermifolium subsp. cariense and Verbascum cariense), and especially the shrublets of Odontarrhena masmenaea (Boiss.) Španiel \& al. (Alyssum masmenaeum) and Phlomis armeniaca. Striking on Altınsivri is the massive occurrence of the lichen Rhizocarpon geographicum (L.) DC., those green-yellow crusts densely cover the peridotite blocks and coarse scree.

The Genistetum sandrasicae displays a large inventory of diagnostic species at association and alliance or suballiance level. All but a local form of the otherwise widespread Chamaecytisus pygmaeus (Fig. 4c), which on Sandras Dağ1 is not always easily distinguishable from Ch. eriocarpus (Boiss.) Rothm. (see also the deviating identification of Quézel 1973 and the confirming of Hartvig \& Strid 1987), are SW Anatolian serpentinophytes; Chamaecytisus pygmaeus functions within the Genistetum sandrasicae as differential species. Cytisopsis pseudocytisus subsp. reeseana (Fig. 4f) is rather a differential species than a character species of the superordinate syntaxon, having a wide altitudinal range from sea-level to the subalpine belt in various serpentinophytic units. It is particularly widespread in the higher elevations of Sandras Dağ1 and occurs in "an extreme mountain ecotype, prostrate, very dense, woody and small-leaved" (Hartvig \& Strid 1987). Interestingly, Quézel (1973) did not record this in flower so eye-catching plant. One can only speculate that it was still in bud due to the earlier sampling season and thus overlooked or mistaken.

The mesomorphic Viola sandrasea (Fig. 3c), although not confined to this association, has within the Genistetum sandrasicae its phytosociological centre of occurrence and differentiates within the Thuryion capitatae the Genistetum sandrasicae from the xeric Odontarrheno masmenaeae-Ebenetum pisidicae. The distribution areas of the character species Aethionema speciosum subsp. compactum (Fig. 4c), Genista sandrasica, Prometheum serpentinicum (Fig. 3j) and Verbascum cariense include the mountain ranges of the Peridotite Nappe. They for example also occur on Tuzla Beli pass (Gök Tepesi, 
Boncuk Dağları), some $40 \mathrm{~km}$ to the SE from Sandras Dağ 1 (pers. comm., R. Ulrich, Tübingen). Genista sandrasica is an espalier shrublet, which was segregated from G. lydia Boiss. as late as 1987 by Hartvig \& Strid. Besides the Fabaceae, the two higher-ranked character species Ebenus pisidica (Fig. 3h) and Odontarrhena masmenaea occur with highest constancy and higher abundance-cover values.

Distribution. - The Genistetum sandrasicae is hitherto recorded from three places in the Sandras Dağı massif (Akköprü Çögenli, Altınsivri, Çicekbaba Tepesi). At least the driest variant of Teucrium alyssifolium ought to have a wider distribution at suitable ultramafic sites in the mountain forest belt of SW Anatolia. This unit is almost certainly present at Tuzla Beli (see Parolly \& Kit Tan 2006).

Subdivision, community differentiation. - With the notable exception of the Teucrium alyssifolium variant (Table 2b), the association (var. typicum; Table 2a) is floristically and physiognomically quite uniform in spite of covering a wide topographical range. Nevertheless, a damp and a dry wing of the type variant can be distinguished, but these units are linked by intermediate stands and, at least at the present state of knowledge, not worth being formally recognised. The rock-strewn sites provide many moist and often wind-sheltered micro-sites, where tiny patches of snow can hang late in the year and support Trifolio-Polygonetalia species, especially Bolanthus frankenioides var. fasciculatus and, at the dampest sites, Plantago holosteum (relevés D4 and D5). The mesomorphic Galium tmoleum marks locally such conditions. It is a low, caespitose and fairly delicate perennial that is indifferent in its substrate requirements. Galium tmoleum is often associated with the Thuryion capitatae species Sabulina verna subsp. brevipetala (Minuartia verna subsp. brevipetala), for which a second locality exists on Bakırlı Dağı in the Lycian Taurus (Eren \& al. 2004). By contrast, Genistetum sandrasicae stands sampled at dryer places display enhanced proportions and numbers of xerophytic graminoids (Festuca valesiaca, Koeleria macrantha, Sesleria alba, Stipa holoserica, and rarely Carex kitaibeliana).

The Teucrium alyssifolium variant clearly stands apart in synecological, physiognomical and floristical respects. More relevés may well show its independent status and further occurrences in montane elevations around the study area. The site studied is a moderately slopping, wind-beaten hilltop in saddle-position $(1800 \mathrm{~m})$. The substrate is \pm a stabilised, dry ophiolitic scree, including large boulders, which supports an open dwarf-shrub community to Astragalus condensatus thorn-cushion community. Suffruticose and creeping chamaephytes dominate, each with about $30 \%$, the physiognomy, and also cushion plants play a somewhat greater role. The differential species include with the tragacanthic Astragalus condensatus, Convolvulus compactus, Thesium billardieri and Cruciata taurica four widespread Astragalo-Brometea species, which have not developed any particular substrate preferences. However, Convolvulus compactus (Fig. 4e) is a good marker for wind-exposed sites, and it has, at least outside the Inner Anatolian steppe communities, a preference for serpentinite. Silene brevicalyx is a rarely recorded local endemic. Finally, Teucrium alyssifolium (Fig. 4h) seems to be the most significant differential species of the variant. Confined to ultramafic soils, it has a narrow SW Anatolian range in the higher elevations of the 
Western Taurus, where it grows often at wind-exposed and rocky places or on serpentine scree (Parolly 2004; Parolly \& Kit Tan 2006; Parolly \& al. 2007).

Syntaxonomic comparison. - The Genistetum sandrasicae matches floristically and ecologically best the groupement à Ebenus pisidica et Plantago carinata (on "cuvettes terreuses") and partly the groupement à Convolvulus cochlearis et Chamaecytisus eriocarpus (on "rocailles compactes de faible inclinaison", Quézel 1973). The earlier distinction of these communities is largely a sampling artefact due to the limited number of relevés and the inclusion of a fairly large number of taxonomically doubtful species, which cannot be assigned to any other taxon with certainty. Quézel's relevés are much poorer in species (many diagnostic species lacking) and display an enhanced proportion of ruderals and antipastorals.

Odontarrheno masmenaeae-Ebenetum pisidicae Parolly, ass. nov.: Wind-swept, serpentinophytic dwarf-shrub community of the Western Taurus (Table 3; Fig. 4b)

Holotypus: Table 3, relevé 16. - CS: Aethionema cordatum subsp. pichleri. DS (loc.): Centaurea drabifolia subsp. cappadocica (weak), Galium incanum subsp. centrale, Minuartia erythrosepala var. erythrosepala, Thesium procumbens (weak). Incl.: Groupement à Alyssum propinquum et Sesleria phleoides (Quézel 1973) p. p.

Site conditions. - Stands of the subalpine Odontarrheno masmenaeae-Ebenetum pisidicae inhabit wind-exposed, sunny sites of the summit region (2100-2260 m) of Sandras Dağ1. They establish themselves on gentle hilltops and rocky slopes covered by debris (Fig. 4b) and boulders, always in exposures ranging between $\mathrm{S}$ and W. Some stands grow on stabilised, dry peridotite scree. Larger amounts of fine soil (5-10\%) are always visible at the surface of the plots of the Odontarrheno masmenaeae-Ebenetum pisidicae. The shallow, immature soil-cover overlays the parent rock, which often crops out, only for some 5$20 \mathrm{~cm}$ and furthers together with the desiccating winds the xeric site conditions. On the other hand, large blocks provide patchily distributed wind-shelter and allow the thriving of a number of hygromorphic to mesomorphic species of the earlier introduced associations within the Odontarrheno masmenaeae-Ebenetum pisidicae.

Structure and floristical composition. - Structurally, the Odontarrheno masmenaeae-Ebenetum pisidicae is clearly dominated by the various types of chamaephytes (77.4\% mpc-value). Thorn-cushions hold only somewhat larger proportions $(4.5 \%)$ than in the previous association and therefore the Odontarrheno masmenaeaeEbenetum pisidicae is best termed as dwarf-shrub community, in which suffruticose $(32.2 \%)$ and creeping chamaephytes (13.5\%) are the key components with almost balanced proportions (see Table 4).

It is typical of wind-swept places to find enhanced figures for non-tragacanthic cushion plants. Compared with the Genistetum sandrasicae this hold true, but a value of $8.3 \%$ is far apart from the dimensions attained in wind-swept Drabo-Androsacetalia communities (mpc-values ranging between 30-60\%, see Parolly 2004) that normally grow in much higher elevations on alkaline substrate. The other life forms in the spec- 
Table 3. The Ebeno pisidicae-Alyssetum masmenaei (Thuryion capitatae, Astragalo-Brometalia) on Sandras Dağı.

\begin{tabular}{|c|c|c|c|c|c|c|}
\hline Relevé no. & 14 & 15 & 16 & 17 & 18 & 19 \\
\hline Locality & 1 & 1 & 1 & 1 & 1 & 1 \\
\hline Altitude (m) & 2100 & 2100 & 2100 & 2120 & 2260 & 2100 \\
\hline Exposure & SSW & $\mathrm{S}$ & W & W & SW & $\mathrm{S}$ \\
\hline Inclination $\left(^{\circ}\right)$ & 20 & 15 & 5 & 5 & 15 & 20 \\
\hline Vegetation cover $(\%)$ & 30 & 20 & 15 & 15 & 30 & 25 \\
\hline Proportion of rocks \& stones (\%) & 65 & 70 & 80 & 80 & 60 & 65 \\
\hline Proportion of fine soil (\%) & 5 & 10 & 5 & 5 & 10 & 10 \\
\hline Square size $\left(\mathrm{m}^{2}\right)$ & 12 & 12 & 12 & 12 & 12 & 12 \\
\hline Number of species & 23 & 17 & 19 & 18 & 20 & 21 \\
\hline \multicolumn{7}{|l|}{ CS \& DS of the association } \\
\hline Galium incanum subsp. centrale & 1 & $2 \mathrm{a}$ & 1 & 1 & 1 & + \\
\hline Minuartia erythrosepala var. erythrosepala & 1 & + & + & + & + & + \\
\hline Aethionema cordatum subsp. pichleri & + & + & + & + & $(+)$ & + \\
\hline \multicolumn{7}{|l|}{ CS \& DS of the Thuryion capitatae } \\
\hline Odontarrhena masmenaea & $2 b$ & $2 \mathrm{a}$ & $2 \mathrm{a}$ & 1 & $2 \mathrm{a}$ & 1 \\
\hline Alyssum propinquum & 1 & 1 & 1 & 1 & 1 & $2 \mathrm{a}$ \\
\hline Acantholimon ulicinum var. purpurascens & + & + & + & + & + & 1 \\
\hline Minuartia recurva subsp. carica & $(+)$ & . & 1 & 1 & 1 & + \\
\hline Ebenus pisidica & $2 \mathrm{a}$ & + & $(+)$ & 1 & 1 & $(+)$ \\
\hline Cyanus reuteranus var. reuteranus & 1 & . & . & 1 & + & + \\
\hline Linum boissieri & . & . & + & 1 & . & + \\
\hline Chamaecytisus pygmaeus & + & . & . & . & . & . \\
\hline Sideritis leptoclada & . & + & . & . & . & . \\
\hline Noccaea leblebicii & $\mathrm{r}$ & . & . & . & . & . \\
\hline \multicolumn{7}{|l|}{ CS \& DS of the Astragalo-Brometalia } \\
\hline Muscari tenuiflorum & + & $1 \mathrm{~m}$ & $1 \mathrm{~m}$ & 1 & 1 & . \\
\hline Scorzonera szowitzii & + & . & 1 & 1 & + & + \\
\hline Centaurea cariensis subsp. maculiceps & + & + & + & + & . & . \\
\hline Campanula stricta var. libanotica & + & . & + & . & . & . \\
\hline $\begin{array}{l}\text { Hypericum aviculariifolium subsp. depilatum var. bourgaei } \\
\text { CS \& DS of the Drabo-Androsacetalia }\end{array}$ & . & . & . & . & 1 & . \\
\hline Centaurea drabifolia subsp. cappadocica & 1 & 1 & 1 & . & + & + \\
\hline Thesium procumbens & + & 1 & + & . & . & . \\
\hline \multicolumn{7}{|l|}{ CS \& DS of the Trifolio-Polygonetalia } \\
\hline Ranunculus heterorhizus & + & 1 & . & . & . & + \\
\hline Scilla pleiophylla & . & . & $1 \mathrm{~m}$ & $1 \mathrm{~m}$ & . & . \\
\hline Plantago holosteum & . & . & . & + & . & + \\
\hline Ornithogalum alpigenum & . & . & . & + & . & + \\
\hline Corydalis oppositifolia subsp. oppositifolia & . & . & . & + & . & + \\
\hline \multicolumn{7}{|l|}{ CS \& DS of the Astragalo-Brometea } \\
\hline Thymus sipyleus subsp. sipyleus & $2 \mathrm{a}$ & + & 1 & 1 & $2 \mathrm{a}$ & $2 \mathrm{a}$ \\
\hline Bromopsis tomentella subsp. tomentella & + & + & + & . & 1 & 1 \\
\hline Arenaria ledebouriana var. ledebouriana (vs. var. pauciflora) & 1 & + & + & + & + & . \\
\hline Prunus prostrata var. prostrata & 1 & 1 & . & & 1 & 1 \\
\hline Paronychia chionaea & 1 & . & 1 & . & . & + \\
\hline Festuca valesiaca & 1 & . & . & . & 1 & + \\
\hline Mattiastrum lithospermifolium subsp. cariense & . & . & . & . & + & + \\
\hline Koeleria macrantha & . & . & . & . & 1 & . \\
\hline Sedum ursi & . & . & . & . & $1 \mathrm{~m}$ & . \\
\hline
\end{tabular}


trum of the Odontarrheno masmenaeae-Ebenetum pisidicae are \pm insignificant, leaving aside the combined mpc-values of the hemicryptophytes $(12.4 \%)$ and of the geophytes $(9.3 \%)$. The open structure (vegetation cover $15-30 \%$ ) of the Odontarrheno masmenaeae-Ebenetum pisidicae perfectly corresponds with its rocky and wind-swept habitat.

In floristic-phytosociological respects, the Odontarrheno masmenaeae-Ebenetum pisidicae seems largely to represent the central association of the Thuryion capitatae alliance, and is much poorer in species than the Genistetum sandrasicae. It is marked rather by the lack of a greater number of mesophytic species of various phytosociological meaning than by displaying many discriminating diagnostic species. Besides the evident absence of the character species of the Genistetum sandrasicae, three taxa differentiate constantly the Odontarrheno masmenaeae-Ebenetum pisidicae positively against the Genistetum. Two of them, Minuartia erythrosepala var. erythrosepala and Galium incanum subsp. centrale, are by no means serpentinophytes, but widespread high-mountain plants indicating wind-exposed sites. The only proper character species, Aethionema cordatum subsp. pichleri, is widely ignored in the Turkish taxonomic literature (including in Davis \& al. 1988), but it in my opinion well deserves formal recognition. In addition to the morphology (see Hartvig \& Strid 1987), a particular range (NW and SW Anatolia) and its substrate preferences support this view. Two further differential species (Centaurea drabifolia subsp. cappadocica and Thesium procumbens) are important elements of the windswept Drabo-Androsacetalia communities of the Taurus, but on Sandras Dağı not exclusive to the Odontarrheno masmenaeae-Ebenetum pisidicae: they also occur in the driest sites of the Genistetum sandrasicae, especially in the Teucrium alyssifolium variant, which bridges the two western associations of the Thuryion capitatae. At such places, too, the quite local serpentinophyte Sideritis leptoclada was also recorded, those phytosociological links remain unresolved. It is notable that especially the indicators for wind-exposure bring in the pulvinate life forms.

Floristically interesting, though phytosociologically insignificant, is the record of the fairly local serpentinophyte Noccaea leblebicii, which may in a wider view be among the character species of the suballiance.

Distribution. - Records of the Odontarrheno masmenaeae-Ebenetum pisidicae are hitherto confined to Çicekbaba Tepesi, the main summit of Sandras Dağı. Provided that the association is here geoecologically correctly outlined as subalpine, wind-swept, serpentinophytic dwarf-shrub community of the Western Taurus, it is unlikely to expect further stations outside Sandras Dağ1, - simply because there are no other serpentinites in the western Taurus culminating 2000 or more metres.

Subdivision, community differentiation. - None. 
Table 4. Distribution of life forms in the communities of Sandras Dağ1.

\begin{tabular}{|c|c|c|c|c|}
\hline Life form (M \%) & 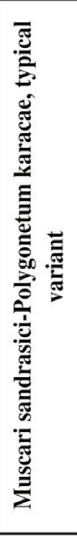 & 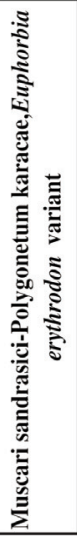 & 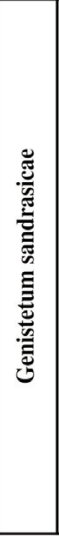 & 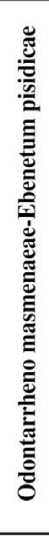 \\
\hline Ch frut acanth (chamaephyta frutescentia acantha) & 2.9 & . & 2.2 & 4.5 \\
\hline Ch herb (chamaephyta herbacea) & 2.2 & 3.1 & 0.6 & \\
\hline Ch pulv (chamaephyta pulvinata) & 29.1 & 20.9 & 3.4 & 8.3 \\
\hline Ch rep/rept (chamaephyta repantia/reptantia) & 1.5 & 9.4 & 48 & 31.5 \\
\hline Ch succ (chamaephyta succulenta) & . & . & 1.2 & 0.9 \\
\hline Ch suffr (chamaephyta suffruticosa) & 9.2 & 12.2 & 19.9 & 32.2 \\
\hline G bulb (geophyta bulbosa) & 19 & 12.8 & 6.7 & 8.6 \\
\hline G rhiz (geophyta rhizomatosa) & . & . & . & 0.7 \\
\hline H caesp (hemicryptophyta caespitosa) & 6.9 & 15.6 & 7.1 & 6.4 \\
\hline H ros (hemicryptophyta rosulata) & 29.2 & 20.3 & 9.3 & 3.3 \\
\hline H scap (hemicryptophyta scaposa) & . & 0.1 & 0.3 & 1 \\
\hline H sem (hemicryptophyta semi-rosulata) & . & 0.1 & 1.3 & 1.7 \\
\hline T scap hpar (therophyta scaposa hemi-parasitica) & . & . & & 0.9 \\
\hline T sem (therophyta semi-rosulata) & . & 5.5 & & . \\
\hline Total $(\%)$ & 100 & 100 & 100 & 100 \\
\hline
\end{tabular}

Syntaxonomic comparison. - The Odontarrheno masmenaeae-Ebenetum pisidicae matches best the "groupement à Alyssum propinquum et Sesleria phleoides" (Quézel 1973). The association is firmly nested in the western race of the Thuryion capitatae and the Astragalo-Brometalia. In spite of the typically wind-swept habitat of Odontarrheno masmenaeae-Ebenetum pisidicae, the set of the Drabo-Androsacetalia character species is weakly represented; taxa typical of the alliance of the Lycian Taurus (Paronychion lycicae Quézel 1973, see Parolly 2004) are notably totally lacking. 


\section{Chorotype spectra}

The chorotype spectra of the communities of Sandras Dağ studied (Table 5) neatly fit most of the expectations for high-mountain vegetation units of the coastal edge of the Taurus range, where E Mediterranean geoelements and genoelements (endemics of E Mediterranean origin) clearly predominate (gp-values from 64,5-79.1\%). Outstanding is, however, the generally high rate of endemism approaching $60 \%$ and especially the hitherto unrivalled high gp-values attained for the proportions of narrow endemics (local endemics + endemics of the Western Taurus) within the communities (Muscari sandrasiciPolygonetum karacae 30.9\%, respectively. 29\%; Genistetum sandrasicae $27.5 \%$; Odontarrheno masmenaeae-Ebenetum pisidicae 20.4\%). Total endemism rates oscillating around $60 \%$ have been occasionally found in xerophytic high-mountain scree plant and rock communities (Parolly 1995, 1998; Hein \& al. 1998), but never to such an extent in hygrophytic Trifolio-Polygonetalia vegetation (Kürschner \& al. 1998; Parolly, unpublished data) or dwarf-shrub units (Astragalo-Brometalia s.1.; Kürschner 1982; Quézel 1973; Parolly, unpublished data). The spectra thus reflect the high degree of local speciation in the SW Anatolian serpentine vegetation. Özhatay \& al. (2003) stress the importance of Sandras Dağ for the conservation of (local) endemics and indicate a total of 81 endemic taxa of various range size.

The other peculiarity of the spectra of Sandras Dağ is that the spectra of hygrophytic units and the meso- to xerophytic units are not different as it would be on limestone and further east. Due to its geographical position, the proportion of the Irano-Turanian (mainly: Irano-Anatolian) element is expectedly low in all communities, although slightly increasing along the xeric gradient from the dry variant of the Muscari sandrasici-Polygonetum karacae to the Odontarrheno masmenaeae-Ebenetum pisidicae. It is noteworthy that there are neither enhanced proportions of Euro-Siberian species nor hygrophytic IranoAnatolian floristic elements in the snow-patch vegetation of Sandras Dağ such places in the Central Taurus and in all eastern ranges (Kürschner \& al. 1998; Parolly, unpublished data).

\section{Dispersal biology of the communities of Sandras Dă̆g}

An analysis of the dispersal biology of the three associations of Sandras Dağ clearly shows the prevailing conditions within them and reflects the sharp contrast between the hygrophytic Muscari sandrasici-Polygonetum karacae (Trifolio-Polygonetalia) that is often found at more wind-sheltered places and the more wind-exposed vegetation of the Thuryion capitatae dwarf-shrub communities (Genistetum sandrasicae, Odontarrheno masmenaeae-Ebenetum pisidicae). Zoochory dominates the spectrum of the Muscari sandrasici-Polygonetum karacae typicum (mpc-value 67\%), while wind dispersal of various types is responsible for similar high percentages in the other two associations.

The montane Euphorbia erythrodon variant of the Muscari sandrasici-Polygonetum karacae, which occurs at much dryer places than the typical variant, bridges largely the chionophytic association with the Thuryion capitatae, in displaying both high zoochorous and boleochoreous mpc-values. Typical of trampled turf vegetation, the proportion of acanthocorous taxa is enhanced. 
Table 5. Distribution of chorotypes in the communities of Sandras Dağı.

\begin{tabular}{|c|c|c|c|c|}
\hline Chorotype (G \%) & 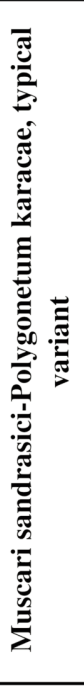 & 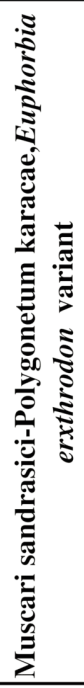 & 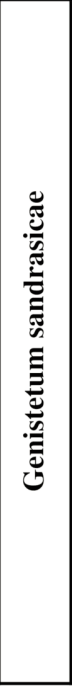 & 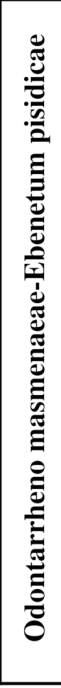 \\
\hline End loc (local endemics) & 20 & 16.1 & 19 & 15.8 \\
\hline End bt (endemics of the Western Taurus) & 10.9 & 12.9 & 8.5 & 4.7 \\
\hline End $\mathbf{t}$ (endemics of the Taurus) & 13.6 & 9.7 & 7.8 & 6.8 \\
\hline End Anatol (Anatolian endemics) & 14.6 & 17.8 & 20.2 & 33 \\
\hline (E)Med ([East] Mediterranean) & 20 & 8 & 18.3 & 9.9 \\
\hline IA (Irano-Anatolian) & & 4.8 & 7.8 & 9.9 \\
\hline EMed-ES (biregional: EMed-Euro-Siberian) & 6.4 & 8.1 & 5.7 & 6.8 \\
\hline EMed-IA (biregional: EMed-IA) & 3.6 & 3.2 & 5.5 & 6.3 \\
\hline tri (triregional: EMed-ES-IA) & 10.9 & 11.3 & 6.7 & 6.8 \\
\hline subcos (subcosmopolitan) & & 8.1 & . & \\
\hline Unidentified (sterile) & & & 0.5 & \\
\hline Total $(\%)$ & 100 & 100 & 100 & 100 \\
\hline
\end{tabular}

The unusual high values of zoochory within the Muscari sandrasici-Polygonetum karacae typicum are due to the principally myxochorous Plantago holosteum, which alone holds a mpc-value of $58.5 \%$. As in most Plantago species, the testa of $P$. holosteum "verschleimt bei Wasserzutritt leicht" (Casper 1974: 565). Myxochory has both a telechorous (long-distance dispersal especially by vertebrates) and an antitelechorous effect (see 
Zohary 1973). The latter effect by sticking the seeds to soil and plant surfaces - may help that a good deal of the diaspores remains within the biocoenosis proper - and this can be a narrow meltwater runnel. Plantago seeds are also often found in the dung of cattle, sheep and goat (Bonn \& Poschlod 1998; Müller-Schneider 1983). Endozoochorous dispersal is here confirmed also for Sandras Dağ1, where the damp patches dominated by Plantago holosteum and grasses are a preferred grazing ground. Pellets of goat dung contained dozens of undamaged seeds of $P$. holosteum together with a few seeds of Caryophyllaceae.

Other zoochorous construction types of diaspores found within stands of the Muscari sandrasici-Polygonetum karacae include a limited number of acanthochorous (Alopecurus gerardii, Poa bulbosa) or elaiosomochorous taxa (e.g., Colchicum figlalii, Gagea bithynica, Euphorbia erythrodon, Ornithogalum alpigenum, Scilla pleiophylla, Viola sandrasea) with low coverage values. Elaiosomochory mostly occurs in combination with a blastochorous diaspore presentation, confirming the general trend of the spectrum, i.e. the prevalence of engychorous mechanisms. The only other relevant dispersal type within the Muscari sandrasici-Polygonetum karacae typicum is semachory (mpc-value $17.1 \%$ ). With the exception of these wind-ballists, anemochory is insignificant within the spectrum.

Exactly these more specialised types of anemochory, especially cyclochory, and to low proportions lophochory, pogonochory, pterochory, characterise together with high percentages of semachory the spectra of the dwarf-shrub communities (Genistetum sandrasicae and Odontarrheno masmenaeae-Ebenetum pisidicae). In total (specialised anemochory + boleochory/semachory), anemochory holds in both associations mpc-values of ca. 70\%. Chaemaechorously dispersed species (cyclochory) predominate in the spectrum of the Genistetum sandrasicae with $31.9 \%$ due to the high cover and abundance values of the two Fabaceae species, Cytisopsis pseudocytisus subsp. reeseana and Ebenus pisidica as well as Cyanus reuteranus var. reuteranus. In the latter species and in Centaurea drabifolia subsp. cappadocica, which however is more important in the Odontarrheno masmenaeae-Ebenetum pisidicae, whole capitula are dispersed by the wind. Another typical Astragalo-Brometea species is Paronychia chionaea, where each light-weight constructed diaspore consists of glomerules 10-15 $\mathrm{mm}$ in diameter, comprising groups of indehiscent fruits (utricles) enclosed in the persistent calyx and concealed by conspicuous, silvery-scarious bracts. As typical of some Minuartia species, the diaspore of M. erythrosepala is a cluster of 5-7 flowers in fruiting state aggregated into almost globular cymes. $M$. erythrosepala is in the Taurus range frequently found at wind-exposed places and here diagnostic of the Odontarrheno masmenaeae-Ebenetum pisidicae.

Although not as enhanced as in alpine and subnival vegetation units, hydrochory (exclusively represented by ombro-hydrochorous types) is better developed in the Genistetum sandrasicae $(6.4 \% \mathrm{mpc})$ and Odontarrheno masmenaeae-Ebenetum pisidicae $(11.9 \% \mathrm{mpc})$ than in the Muscari sandrasici-Polygonetum karacae. Its proportions are positively correlated with increasing elevation. Typical rain-ballists of the Sandras Dağ include mainly Brassicaceae such as Aethionema cordatum subsp. pichleri, Ae. speciosum subsp. compactum, Alyssum propinquum (Fig. 3i), Iberis sempervirens and Noccaea leblebicii, the Crassulaceae species, Prometheum serpentinicum and Sedum ursi as well as Muscari tenuiflorum. 
Table 6. Distribution of dispersal types in the communities of Sandras Dağ1.

\begin{tabular}{|c|c|c|c|c|}
\hline Construction type of diaspores & 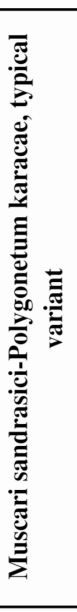 & 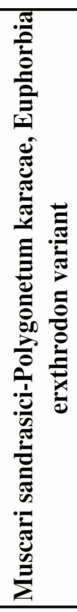 & 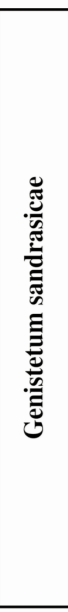 & 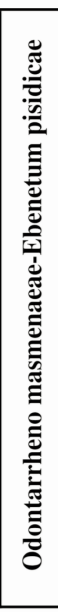 \\
\hline acanth (acanthochorous) & 2.2 & 8.5 & 3.8 & 2.2 \\
\hline ball (ballochorous) & 5.1 & 3.1 & 10.2 & 6.3 \\
\hline blast (blastochorous) & 6.7 & 12 & 2 & 1.8 \\
\hline bole (boleochorous) & 17.1 & 30.8 & 27,7 & 49.5 \\
\hline cyclo (cyclochorous) & 0.7 & 0,3 & 31.9 & 12.8 \\
\hline ela (elaiosomochorous, myrmecochorous) & 6.3 & 2.9 & 2.3 & 3.3 \\
\hline herp (herpochorous) & - & . & 0.7 & 0.8 \\
\hline hydro (ombrohydrochorous) & 3.4 & 1.9 & 6.4 & 11.9 \\
\hline loph (lophochorous) & 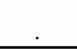 & 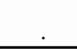 & 0.7 & 0.5 \\
\hline myx (myxochorous) & 58.5 & 36.6 & 4.4 & 1.2 \\
\hline pogo (pogonochorous) & & 2 & 3.7 & 1.7 \\
\hline pter (pterochorous) & & 1.9 & 6.2 & 5.1 \\
\hline sarc (sarcochorous) & & & 0.1 & 2.9 \\
\hline Total $(\%)$ & 100 & 100 & 100 & 100 \\
\hline
\end{tabular}

\begin{tabular}{|l|c|c|c|c|}
\hline Specialised anemochory & 0,7 & 4,2 & 42,5 & 20,1 \\
\hline Semachory & 17,1 & 30,8 & 27,7 & 49,5 \\
\hline Anemochory \& semachory & 17,8 & 35,0 & 70,2 & 69,6 \\
\hline Autochory & 11,8 & 15,1 & 12,9 & 8,9 \\
\hline Hydrochory & 3,4 & 1,9 & 6,4 & 11,9 \\
\hline Zoochory & 67 & 48 & 10,5 & 9,6 \\
\hline
\end{tabular}




\section{Concluding remarks}

The present paper reconsiders and re-evaluates the tree-less high-mountain vegetation of Sandras Dağ1. We thus have the first outline of the vegetation types on peridotite of the wider range: for an account of the forest vegetation, see Akman \& al. (1979) and Özhatay (1987); for the scrub vegetation of the nearby Köyceğiz-Dalyan Specially Protected Area, see Vural \& al. (1995). The present contribution focuses on the edaphically differentiated Astragalo-Brometea communities sensu Parolly (2004), i.e. including meltwater and snowbed vegetation. A study of the hygrophytic vegetation (e.g., flushes) lining the brooklets, although recorded in grazed and devastated stands, is omitted here and will be published elsewhere.

The main phytosociological results are compiled in Table 7. Three high-mountain vegetation units are treated in detail (Tables 1-3); all three represent new associations, which only in part fit into Quézel's generally accepted groupements (Gemici \& al. 1994; Gemici \& Görk 1995; Quézel 1973). Two associations are zonal (Genistetum sandrasicae, Odontarrheno masmenaeae-Ebenetum pisidicae), both grouped in the Thuryion capitatae and Astragalo-Brometalia. The third is azonal and confined to snow-beds (Muscari sandrasici-Polygonetum karacae, Thlaspion papillosi, Trifolio-Polygonetalia), which however are locally due to the geological substrate abundant and extensive. All units are extraordinary rich in endemic species of various subcategories; especially noteworthy is the high percentage of narrow endemics within the communities (ca. 20-30\%).

Establishing three new associations and, below, a new suballiance on the base of just four dozens of relevés that all come from a single mountain massif, seems justified, if one considers that Sandras Dağ 1 is the only place in the Western Taurus, where the unique subalpine vegetation on ultramafic soils can be studied. The subalpine and hygro- to mesophytic units are thus confined to this area, while there are some outposts of xerophytic stands at montane elevations (Teucrium alyssifolium variant of the Genistetum sandrasicae), of whom we have floristic field notes for comparison (Parolly \& Kit Tan 2006). Already in the western edge of the Central Taurus, the serpentinophytic Astragalo-Brometalia units are clearly different from the communities described here.

Thuryion capitatae - the montane and subalpine serpentinophytic vegetation of the $S$ Anatolian Taurus range

\section{Thuryion capitatae Quézel ex Parolly}

Nomenclatural type (holotypus): Leontodonto asperrimi-Pseudosempervivietum sempervivi Quézel ex Parolly, nom. mut. prop., hoc loco. - CS and DS: See Fig. 5.

Note: The name Thuryion capitatae is typified by its single subordinate element, the Leontodonto asperrimi-Cochlearietum sempervivi Quézel ex Parolly, nom. mut. prop., hoc loco (holotypus: Quézel 1973, Table 22: relevé 1). Quézel in Quézel \& al. (1992: 82) failed to validate the name Thuryion capitatae by this association, when he transformed the rankles "groupement à Cochlearia sempervivum et Leontodon masmeneanum" (Quézel 1973) into the "Leontodo masmeneani-Cochlearietum sempervivi Quézel 1973" (Quézel \& al. 1992) without indicating a type relevé for the association (art. 5, 9 ICPN, Weber \& al. 2000). The above lecto-typification of the association validates the Thuryion capitatae. 
Since Leontodon masmeneum Boiss. \& Bal. is nowadays considered a synonym of $L$. asperrimus (Willd.) J. Ball (Kupicha 1975) and Cochlearia sempervivum was shown to be a member of the genus Pseudosempervivum (Boiss.) Grossh., I propose here for the validated association a nomen mutatum in accordance with art. 45 ICPN (Weber \& al. 2000).

Leontodon asperrimus is indifferent to the substrate and occurs in a wide range of habitats, although I have observed a certain preference for ultramafic soils. It differentiates the Thuryion capitatae against the basiphytic alliances, where it is widely replaced by $L$. oxylepis Boiss. \& Heldr. The most characteristic species of the Thuryion capitatae alliance and its two suballiances are true indicators of serpentine, which in their vast majority have been proven to be nickel (and cobalt) hyperaccumulators (Brooks 1987; Kruckeberg \& al. 1999; Reeves \& Adıüzel 2004). Centaurea drabifolia subsp. cappadocica differentiates in the western part of the Taurus the Thuryion against the basiphytic Astragalo-Brometalia alliances; in the Cilician Taurus this taxon has two centres of occurrences: Mid-elevation serpentine areas (Thuryion communities) and the basiphytic, wind-swept oroxerophytic vegetation of the summit regions (Drabo-Androsacetalia communities).

The Thuryion capitatae in the Western Taurus. - The xerophytic to mesophytic Genistetum sandrasicae and Odontarrheno masmenaeae-Ebenetum pisidicae associations of Sandras Dağı are attached to the here modified and validated Thuryion capitatae Quézel ex Parolly alliance (for character and differential species see Fig. 5, for its formal validation, see below). By contrast, Quézel (1973), and in suite Gemici \& Görk (1995) linked up the communities of Sandras Dağ1 (groupement à Convolvulus cochlearis et Chamaecytisus eriocarpus, groupement à Alyssum propinquum et Sesleria phleoides, groupement à Ebenus pisidica et Plantago carinata) with the Tanacetion praeteriti on account of the occurrence of the following character species of the alliance: Astragalus sibthorpianus (as A. paecilanthus), Bornmuellerantha aucheri (as Odontites aucheri) and Dianthus eretmopetalus. Today, the Tanacetion is accepted with an almost completely revised set of diagnostic species (see Parolly 2004; Eren \& al. 2004), to comprise only basiphytic montane to subalpine thorn-cushion communities, open grasslands and dwarf-shrub communities.

To accommodate the westernmost communities of the serpentinophytic Thuryion capitatae, I suggest here the suballiance Ebenenion pisidicae Parolly, suball. nov. (Holotypus: Genistetum sandrasicae). For a full list of its character and differential species, see Fig. 5.

Some of these diagnostic species may deserve brief comments: In their majority, they are not confined to high-mountain ecosystems; Odontarrhena masmenaea, Cytisopsis pseudocytisus subsp. reeseana and Sideritis leptoclada for example also differentiate forest communities at lower elevations such as the "Association à Pinus brutia et Cytisopsis dorycniifolia subsp. reeseana" Akman \& al. (Akman \& al. 1979). With the exception of the substrate-vag Aethionema cordatum subsp. pichleri, Cyanus reuteranus and Galium incanum subsp. centrale, the bulk of the taxa are closely linked to ultramafites. Most of them are SW Anatolian endemics. Polygonum karacae (for the range see Eren \& al. 2004), Ferulago sandrasica (pers. obs.) and Stipa cacuminis (Parolly and Scholz 2004) extend, though with considerable disjunctions, to the western parts of the Central Taurus, where they are components of the local serpentine vegetation (see, Aytaç \& al. 2006; Parolly \& Scholz 2004). 
Table 7. Synoptic table of the Thuryion capitatae. Constancy is given in \%. - Localities: For own relevés, see Appendix 2; AY Acımam Yayları, SD Sandras Dağı (both from Quézel 1973). [Taxa occurring in only one column (community with constancy $<20.1 \%$ as well as taxy with unclear taxonomic identidy in Quézel (1973) have been omitted]... (continue)

\begin{tabular}{|c|c|c|c|c|c|c|c|c|c|}
\hline Community & 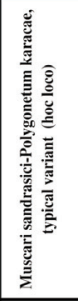 & 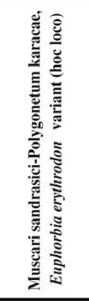 & 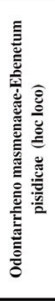 & 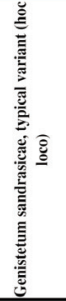 & 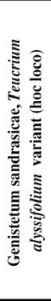 & 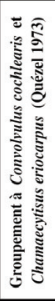 & 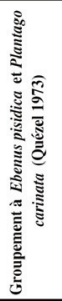 & 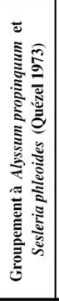 & 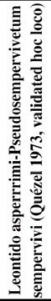 \\
\hline Locality & $2-4$ & 6 & 1 & $7-8$ & 5 & SD & SD & SD & $\mathrm{AY}$ \\
\hline Altitudinal range (min.) & 1900 & 1650 & 2100 & 1950 & 1800 & 2000 & 1800 & 900 & 2000 \\
\hline Altitudinal range (max.) & 2100 & 1650 & 2260 & 2190 & 1800 & 2100 & 2100 & 2150 & 2200 \\
\hline Exposure & $\mathrm{N}, \mathrm{W}(\mathrm{S})$ & NNE-ENE & S-W & S, E, W & $\mathrm{s}$ & S-SW & S-SE & $\mathrm{S}-\mathrm{W}$ & NE-S \\
\hline Inclination $\left({ }^{\circ}\right)$ & $0-25$ & $2-4$ & $5-20$ & $0-42$ & $10-20$ & 8 & 0.5 & $?$ & $10-15$ \\
\hline Average vegetation cover $(\%)$ & 58 & 50 & 23 & 55 & 28 & 53 & 78 & 63 & 66 \\
\hline Average proportion of rocks \& stones $(\%)$ & 38 & 33 & 70 & 27 & 58 & $?$ & $?$ & $?$ & $?$ \\
\hline Average proportion of fine soil (\%) & 19 & 17 & 7.5 & 16 & 5 & $?$ & $?$ & $?$ & $?$ \\
\hline Average square size $\left(\mathrm{m}^{2}\right)$ & 13.7 & 11 & 12 & 29.8 & 24 & 100 & 62.5 & 100 & 100 \\
\hline Number of relevés & 9 & 3 & 6 & 15 & 2 & 3 & 4 & 4 & 5 \\
\hline Average number of species/relevé & 14.2 & 20.7 & 19.7 & 27.9 & 36 & 13 & 16.8 & 16.3 & 33.6 \\
\hline \multicolumn{10}{|l|}{ CS \& DS of the associations } \\
\hline Ranunculus heterorhizus & 100 & 33 & 50 & . & . & . & . & . & . \\
\hline Barbarea brachycarpa subsp. anfractuosa & 89 & 100 & . & . & . & . & . & . & . \\
\hline Muscari sandrasicum & 78 & 100 & . & . & . & . & . & . & . \\
\hline Polygonum karacae [*as $P$. setosum (tax.)] & 67 & 100 & . & . & . & . & $50 *$ & $25^{*}$ & . \\
\hline Euphorbia erythrodon & . & 100 & . & . & . & & & . & . \\
\hline Herniaria glabra & . & 100 & . & . & . & . & . & . & . \\
\hline Petrorhagia alpina subsp. olympica & . & 67 & . & . & . & . & . & . & . \\
\hline Rumex acetosella & . & 67 & . & . & . & . & . & . & . \\
\hline Tragopogon olympicus & . & 33 & . & . & . & . & . & . & . \\
\hline Aethionema cordatum subsp. pichleri & . & . & 83 & . & . & . & . & . & \\
\hline Galium incanum subsp. centrale & 44 & . & 100 & . & . & 33 & 25 & 50 & . \\
\hline Minuartia erythrosepala var. erythrosepala & . & . & 100 & & . & $\dot{-}$ & - & & 60 \\
\hline Genista sandrasica [" as G. ef. lydia (tax.)] & 11 & 33 & . & 80 & 100 & - & $75^{*}$ & . & . \\
\hline Chamaecytisus pygmaeus [" as Ch. eriocarpus + Cytisopsis p. subsp. reeseana? (rev.)] & . & . & 17 & 60 & 100 & $100^{*}$ & {$[25 *]$} & . & . \\
\hline Aethionema speciosum subsp. compactum & 11 & . & . & 87 & 100 & . & . & . & . \\
\hline Verbascum cariense & . & . & . & 47 & 100 & . & . & . & . \\
\hline Prometheum serpentinicum & . & . & . & 40 & 50 & . & . & . & . \\
\hline Cytisopsis pseudocytisus subsp. reeseana [* as Chamaecytisus eriocarpus (rev.)] & . & . & . & 100 & . & . & {$[25 * ?]$} & . & . \\
\hline Scorzonera sandrasica & . & & . & 13 & . & - & - & & . \\
\hline Teucrium alyssifolium & . & . & . & . & 100 & 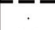 & . & - & . \\
\hline Convolvulus compactus [* as $C$. cochlearis (syn.)] & . & . & . & . & 100 & $100^{*}$ & & . & . \\
\hline Astragalus condensatus [incl. A. podperae] & . & . & . & . & 100 & & & . & . \\
\hline Thesium billardieri & . & . & . & . & 100 & & & . & . \\
\hline Silene brevicalyx $\left[{ }^{*}\right.$ as $S$. tunicoides (tax.)] & . & . & . & . & 100 & & & $25^{*}$ & . \\
\hline Cruciata taurica & . & . & . & . & 100 & . & . & . & . \\
\hline \multicolumn{10}{|l|}{ CS \& DS of the Thuryion capitatae and the Ebenion pisidicae } \\
\hline Odontarrhena masmenaea [" as Alyssum masmenaeum (syn.)] & 78 & 100 & 100 & 93 & 100 & $100^{*}$ & $75^{*}$ & $25 *$ & $40^{*}$ \\
\hline Leontodon asperrimus [" as L. masmenaeus (syn.)] & . & . & . & 40 & 100 & 33 & 50 & . & $80^{*}$ \\
\hline Acantholimon ulicinum var. purpurascens $\left[^{\text {"* }}\right.$ as A. echinus (tax.)] & . & . & 100 & 87 & . & $100^{*}$ & $75^{*}$ & $100^{*}$ & $40^{*}$ \\
\hline Alyssum propinquum & . & . & 100 & 73 & . & 33 & 75 & 100 & . \\
\hline Iberis sempervirens & 11 & . & . & 53 & . & . & 25 & 50 & 40 \\
\hline Convolvulus libanoticus [* as $C$. cf. cataonicus (rev.)] & . & . & & -7 & & & $75^{*}$ & & 100 \\
\hline Cyanus reuteranus var, reuteranus [Centaurea reuterana var, reuterana] & 11 & 67 & 67 & 87 & 50 & - & 75 & 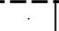 & . \\
\hline Ebenus pisidica & . & . & 67 & 100 & 100 & . & 100 & . & . \\
\hline Fumana aciphylla & . & . & . & 40 & 100 & . & 50 & . & . \\
\hline Viola sandrasea subsp. sandrasea & 44 & 67 & . & 87 & . & . & & . & . \\
\hline Sabulina verna subsp. brevipetala [Minuartia verna subsp. brevipetala] & 44 & 100 & . & 47 & . & & & . & . \\
\hline Linum boissieri & . & 33 & 50 & 47 & . & & & . & . \\
\hline Minuartia recurva subsp. carica & . & . & 67 & 33 & . & & 100 & . & . \\
\hline Sideritis leptoclada & . & . & 17 & . & 100 & & & . & . \\
\hline Galium tmoleum & . & 33 & . & 47 & . & & & . & . \\
\hline Ferulago sandrasica & . & . & . & 27 & . & . & . & 25 & \\
\hline
\end{tabular}


Table 7. continued.

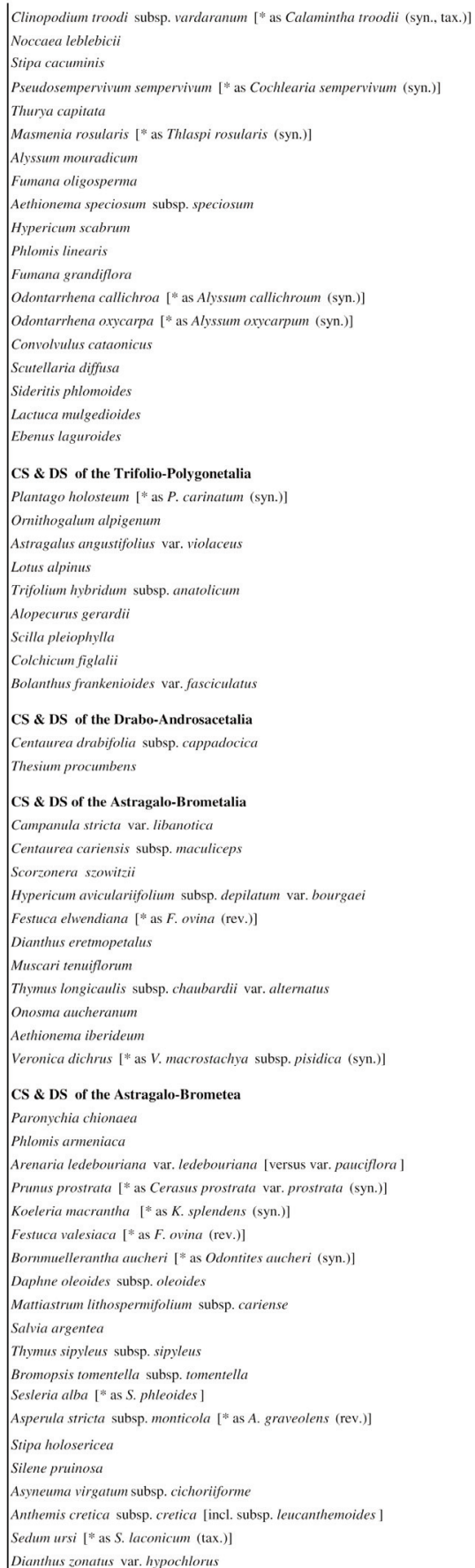

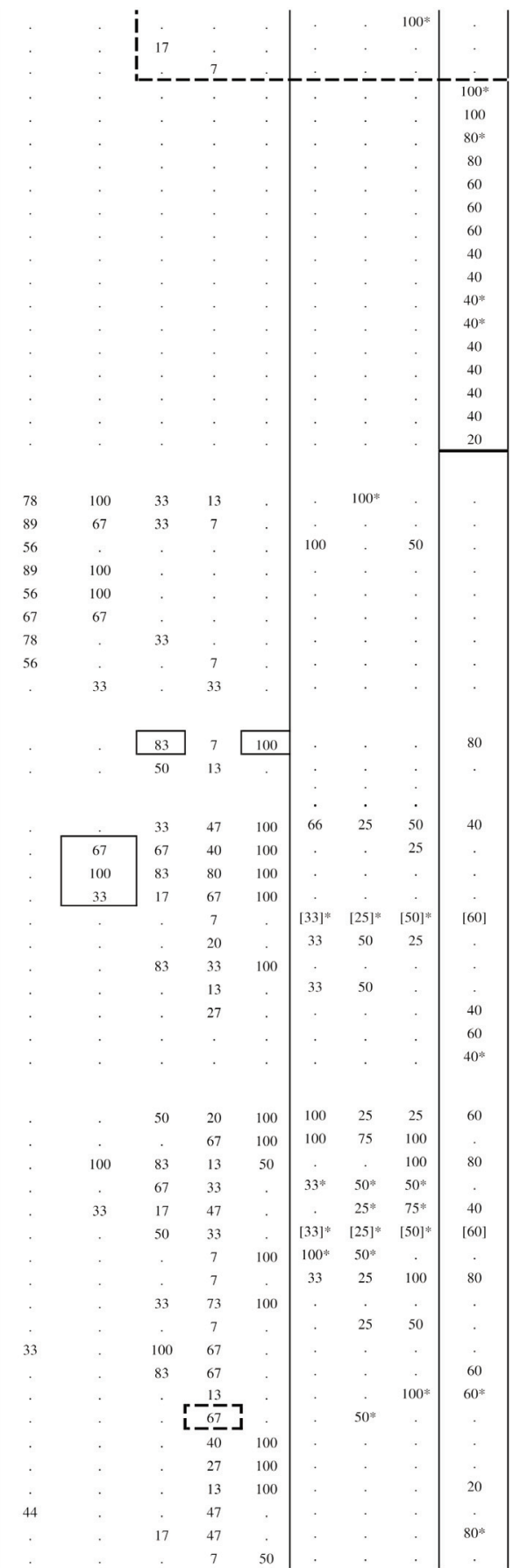


Table 7. continued.

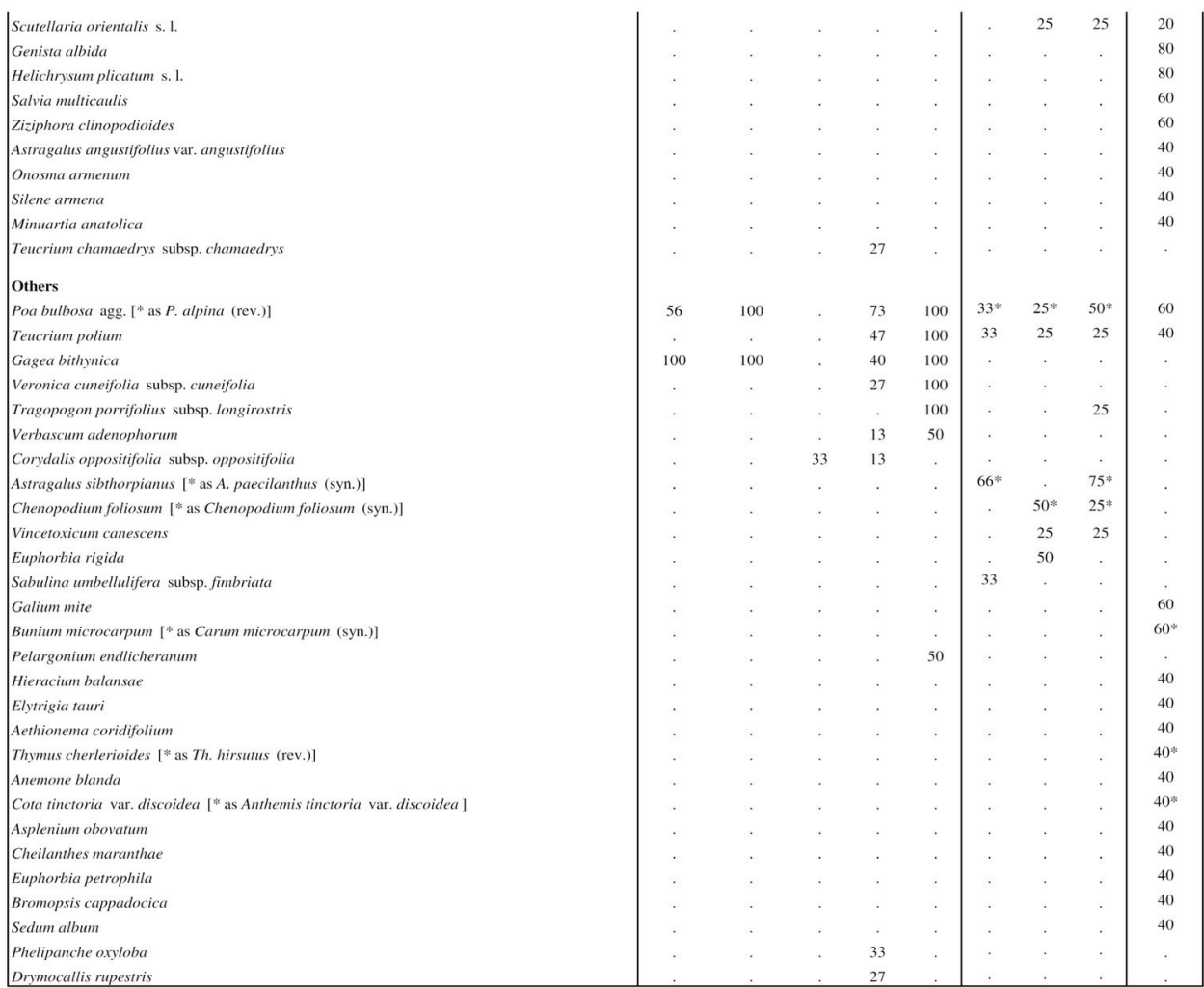

All available relevés of the Thuryion capitatae are compared in a synoptic scheme (Table 7). As far as possible, the names of Quézel's taxa listed in his groupements (1973) have been transferred into the current taxonomy and nomenclature, thus making an interpretation necessary. A certain deal of names, e.g. Scabiosa brevicaulis, could not be clarified. For other problems related to Quézel's units see the comments under 4.1.2. Table 7 shows the independent status of the Ebenenion pisidicae and its two subordinate associations.

Interestingly, not all montane vegetation units of the Western Taurus, which grow on ultramafic soil fit neatly into the Ebenenion pisidicae. Open stands with abundant Astragalus creticus on local and small-scaled ultramafic outcrops on Bakırlı Dağ1, which are in close contact with limestone vegetation, represent rather a depauperate Tanacetion praeteriti community (Astragalo-Brometalia) than an Ebenenion pisidicae unit (Eren \& al. 2004). Only two character species of the Thuryion capitatae have been recorded (Sabulina verna subsp. brevipetala, Polygonum karacae). Alyssum huber-morathii is here another faithful serpentinophyte, which however is more often associated to open mountain forests. The same situation (also true in other formations) is frequently encountered in the 
Central Taurus, where patchy mosaics of limestone and ultramafic soils apparently never support vegetation dominated by serpentinophytes (Parolly 2004). In addition, the syntaxonomic position of the Astragalus creticus community is badly resolved due to the low elevation, where already elements of the Onobrychido armeni-Thymetalia leucostomi Akman \& al. 1984 steppe communities predominate (for problems of distinguishing this order at it upper distributional limit from the Astragalo-Brometalia, reference can be made to Parolly 2004 and Kürschner \& Parolly 2012). Nevertheless, broadening the concept of the Thuryion capitatae allows now the classification of the high montane and subalpine serpentinophytic Astragalo-Brometalia vegetation of the Taurus System.

The eastern stands of the Thuryion capitatae are placed in the Thuryenion capitatae Parolly, suball. nov., hoc loco (holotypus: as in alliance). For its differential species, see Fig. 5, for site conditions and distribution, Quézel (1973).

Proposed FFH Directive Habitat listing of the Thuryion capitatae and other serpentinophytic vegetation of Turkey. - The serpentinophytic vegetation in Turkey, though comparatively widespread (Fig. 1; Brooks 1987; Kruckeberg \& al. 1999; Reeves \& Adigüzel 2004), is underrecorded from a phytosociological point of view. There are no relevés available that would document it from lowland and steppe areas. The single higher-ranked syntaxonomic unit presently defined, the Thuryion capitatae, has its strongest affinities with the substrate-analogous vegetation of the Trodoos range in Cyprus, which is composed both by E Mediterranean elements (Odontarrhena cyprica (Nyár.) Španiel \& al. [Alyssum cypricum Nyár.], Hypericum confertum Choisy subsp. stenobotrys (Boiss.) Holmboe, etc.), or local endemics which are closely related to Anatolian species. Such vicarious and pseudovicarious pairs of taxa include Clinopodium troodii (Post) Govaerts subsp. troodii (Cyprus) vs. C. troodi subsp. vardaranum (Leblebici) Govaerts (incl. subsp. grandiflorum (Hartvig \& Strid) Govaerts (SW Anatolia), Odontarrhena akamasica (B. L. Burtt) Španiel \& al. [Alyssum akamasicum B. L. Burtt], O. chondrogyna (B. L. Burtt) Španiel \& al. [A. chondrogynum B. L. Burtt] and O. troodi (Boiss.) Španiel \& al. [A. troodii Boiss.] (Cyprus) vs. O. masmenaea (Anatolia) and Onosma troodii Kotschyi (Cyprus) vs. O. frutescens Lam., etc. (Meikle 1977-1985).

The present "Interpretation Manual of the European Union Habitats" of the FFH Directive of the European Union lists the relevant vegetation type of Cyprus as "62B0 Serpentinophilous grasslands" (European Commission 2007). With slight emendations and an altered species inventory, this category could be also adopted for the harmonised Habitat list of Turkey to cover all serpentinophytic Astragalo-Brometea communities.

\section{Short comments on the other higher-ranked vegetation syntaxa of Sandras Dağl}

In the light of the revision of the Thuryion capitatae and the separation of Ebenenion pisidicae, the other tree-less high-mountain vegetation units / formations are better understood and allow an outlook considering a wider geographical range:

Meltwater communities and doline vegetation (Trifolio-Polygonetalia). - The Muscari sandrasici-Polygonetum karacae is the first community described from ultramafic soils. Due to the many serpentinophytes, it fits only with some reservation 
Thuryion capitatae Quézel ex Parolly hoc loco

[Range: S + SW Anatolia]

CS: Alyssum propinquum, Convolvulus libanoticus, Fumana aciphylla, Odontarrhena masmenaea (Alyssum masmenaeum), O. oxycarpa (A. oxycarpum), Pseudosempervivum sempervivum (Cochlearia sempervivum), Viola sandrasea s.l.

DS: Acantholimon ulicinum var. purpurascens, Centaurea drabifolia subsp. cappadocica (weak), Iberis sempervirens, Leontodon asperrimus (L. masmenaeus, weak).

\begin{tabular}{|c|c|}
\hline $\begin{array}{l}\text { Ebenenion pisidicae suball. nov. } \\
\text { [Range: Western Taurus + Western Central Taurus] }\end{array}$ & $\begin{array}{c}\text { Thuryenion capitatae suball. nov. } \\
\text { [Range: Cilician Taurus] }\end{array}$ \\
\hline $\begin{array}{l}\text { CS: Aethionema cordatum subsp. pichleri, Cytisopsis } \\
\text { pseudocytisus subsp. reeseana, Ebenus pisidica, Feru- } \\
\text { lago sandrasica, Linum boissieri, Minuartia recurva } \\
\text { subsp. carica, Sabulina verna subsp. brevipetala } \\
\text { (Minuartia verna subsp. brevipetala), Stipa cacuminis, } \\
\text { Teucrium alyssifolium, Verbascum cariense. }\end{array}$ & $\begin{array}{l}\text { CS: Alyssum mouradicum (local), Convolvulus cata- } \\
\text { onicus, Fumana grandiflora, F. oligosperma, Lactuca } \\
\text { mulgedioides (L. seticuspis), Masmenia rosularis } \\
\text { (Thlaspi rosulare), Odontarrhena callichroa (Alyssum } \\
\text { callichroum), O. oxycarpa (A. oxycarpum), Phlomis } \\
\text { linearis, Thurya capitata. }\end{array}$ \\
\hline $\begin{array}{l}\text { DS geogr.: Cyanus reuteranus, Galium incanum } \\
\text { subsp. centrale, Polygonum karacae, Sideritis } \\
\text { leptoclada. }\end{array}$ & $\begin{array}{l}\text { DS geogr.: Aethionema speciosum subsp. speciosum, } \\
\text { Ebenus laguroides, Scutellaria diffusa, Sideritis } \\
\text { phlomoides. }\end{array}$ \\
\hline
\end{tabular}

\begin{tabular}{|l|c|}
\hline \multicolumn{1}{|c|}{ Genistetum sandrasicae ass. nov. } & $\begin{array}{c}\text { Leontodonto asperrimi-Cochlearietum sempervivi } \\
\text { Quézel ex Parolly, hoc loco } \\
\text { [Range: Sandras Dağ1 \& adjacent areas] }\end{array}$ \\
[Range: Cilician Taurus]
\end{tabular}

\section{Odontarrheno masmenaeae-Ebenetum pisidicae} ass. nov.

[Range: Sandras Dağı \& adjacent areas]

\section{CS: Aethionema cordatum subsp. pichleri.}

DS: Centaurea drabifolia subsp. cappadocica (weak), Galium incanum subsp. centrale, Minuartia erythrosepala var. erythrosepala, Thesium procumbens (weak).

Fig. 5. Syntaxonomic subdivision of the Thuryion capitatae of the Taurus range $[\mathrm{CS}=$ character species, DS = differential species, geogr. = geographical]. 
into the Thlaspion papillosi alliance (which hitherto encompassed basiphytic meltwater communities and doline turf only), but well into the Trifolio-Polygonetalia. The association ought to be quite special of Sandras Dağ 1 , since there is no other mountain in the Western Taurus, which would provide suitable conditions for it or another chionophytic vegetation unit. Any re-classification would depend on the discovery of similar stands on ultramafics further east. At least in the serpentine areas, which I have studied (Dedegöl Dağları, Oyuklu Dağı, Bolkar Dağları, Aladağları), this is not very likely.

Rock vegetation (Silenetalia odontopetalae). - The cliffs and rocks sampled in the upper elevations of Sandras Dağı did not support Silenetalia odontopetalae vegetation proper, but fragments of both associations of the Ebenenion pisidicae (Astragalo-Brometalia) together with a very few chasmophytes such as Potentilla speciosa Willd. Viola sandrasea and Prometheum serpentinicum, etc. are important components of these communities and clearly no chasmophytes. Therefore, it not possible to accept a local chasmophytic "groupement à Viola sandrasea et Rosularia serpentinicum" among the Silenetalia odontopetalae as proposed by Quézel (1973). The soft weathering forms of the peridotites of the summit region of Sandras Dağ1 prevent the occurrence of larger cliffs and thus of a particular serpentinophytic rock fissure plant community. In mid-elevations (1400-1700 m) of the massif, shady serpentine rock faces within the forests support mostly monospecific stands of Lamium sandrasicum P. H. Davis (Robert Ulrich, pers. obs.), which appears to be a chomophyte.

Scree vegetation (Lamietalia cymbalariifolii Parolly 1995, Heldreichietea Quézel ex Parolly 1995). - The field work on Sandras Dağ 1 and the records of Lamium sandrasicum from rocks revealed my earlier assumption of a serpentinophytic Lamium sandrasicum scree plant community, substrate vicarious to the basiphytic Lamietum cymbalariifolii Parolly 1995 of the Western Taurus, to be an unsupported speculation (Parolly 1995, 1998, see also the site conditions of L. sandrasicum outlined by Mill 1982). In reality, there are no mobile talus slopes on Sandras Dağ1 at all and the stabilised mounts and block scree are, depending on the exposure and water supply, either covered by stands of the Ebenenion pisidicae or by an often fragmentary Muscari sandrasici-Polygonetum karacae. In lower elevations, in the mountain forest belt, the localised serpentinophytes Eryngium thorifolium Boiss., Jacobaea sandrasica (P. H. Davis) B. Nord. \& Greuter (Senecio sandrasicus P. H. Davis), Noccaea cariensis (Carlström) Parolly \& al. (see Aytaç \& al. 2006), Teucrium sandrasicum O. Schwarz, Verbascum cariense and V. trapifolium (Stapf) Hub.-Mor. are together with many other species frequently associated with patches of scree, deep beds of gravel or even road banks without forming a particular community.

Vegetation of wind-swept sites (Drabo-Androsacetalia). - Another important finding is that the communities of the Drabo-Androsacetalia vegetation are, at least in the western part of the Taurus, exclusively basiphytic. This order classifies the windswept zonal alpine and subnival cushion plant communities as well as subalpine stands of the Taurus System (Parolly 2004). On Sandras Dağ1, it is replaced by the Odontarrheno masmenaeae-Ebenetum pisidicae (Astragalo-Brometalia), which 
shows especially in its dispersal spectrum (in particular the high proportion of cyclochorous species) many affinities with the Drabo-Androsacetalia.

Özhatay \& al. (2003) list Sandras Dağ in floristical respects among the Important Plant Areas (IPAs) of Turkey; this holds certainly also for its serpentinophytic highmountain vegetation. The phytosociological fundaments of its understanding were goal of the present paper.

\section{Acknowledgements}

The study was supported by a gratefully acknowledged research grant given by the Deutsche Forschungsgemeinschaft (DFG: Pa 747/1-2). Prof. Dr Neriman Özhatay (İstanbul) kindly assisted in applying for the research permit (no. 017850) by the Turkish Government. I am particularly grateful to Dipl. Biols. Markus Döring and Darko Tolomir, who shared all burdens and joy of the field work in 1999. They assisted in studying the two meso- and xerophytic vegetation units within the framework of their diploma theses. Prof. Dr Harald Kürschner (Berlin) kindly read a draft version of the manuscript; Mrs. Sandy Berger improved it linguistically. Dr Robert Lücking (BGBM Berlin) provided the equipment for digitising my slides. Michael Rodewald (BGBM Berlin) carefully prepared the maps (Figs. 1, 2). Last but not least, I wish to thank Mrs Birgit Nordt (BGBM Berlin) for her PC-related technical assistance.

\section{References}

Akman, Y., Barber, M. \& Quézel, P. 1979: Contribution à l'étude de la végétation forestière d'Anatolie méditerranéenne. - Phytocoenologia 5(1): 1-79; 5(2): 189-276; 5(3): 277-346.

Aytaç, Z., Nordt, B. \& Parolly, G. 2006: A new species of Noccaea (Brassicaceae) from South Anatolia, Turkey. - Bot. J. Linn. Soc. 150: 409-416. https://doi.org/10.1111/j.10958339.2006.00472.x

Barkman, J. J., Doing, H. \& Segal, S. 1964: Kritische Bemerkungen und Vorschläge zur quantitativen Vegetationsanalyse. - Acta Bot. Neerl. 13: 394-419. https://doi.org/10.1111/j.1438-8677.1964.tb00164.x

Böhling, N. \& Scholz, H. 2003: The Gramineae (Poaceae) flora of the Southern Aegean islands (Greece). Checklist, new records, internal distribution. - Ber Inst LandschaftsPflanzenökologie Univ Hohenheim, Beih 16.

Bolliger, M. 1996: Monographie der Gattung Odontites (Scrophulariaceae) sowie der verwandten Gattungen Macrosyringion, Odontitella, Bornmuellerantha und Bartsiella. Willdenowia 26: 37-168. https://doi.org/10.3372/wi.26.2603

Boissier, E. 1867-1884: Flora Orientalis, 1-5. 1867 (Vol. 1); 1872 (2); 1875 (3); 1975-1879 (4); 1882-1884 (5). - Basiliae, Genevae.

Bonn, S. \& Poschlod, P. 1998: Ausbreitungsbiologie der Pflanzen Mitteleuropas. Grundlagen und kulturhistorische Aspekte. - Wiesbaden.

Braun-Blanquet, J. 1964: Pflanzensoziologie. Grundzüge der Vegetationskunde, Aufl 3. Wien, New York.

Brooks, R. R. 1987: Serpentine and its vegetation. A multidisciplinary approach. - Portland.

Brunn, J. H., Dumont, J. F., Graciansky, P. C., Gutnic, M., Juteau, T., Marcoux, J., Monod, O. \& Poisson, A. 1971: Outline of the geology of the Western Taurids. - Pp. 225-255 in: Campbell, A. S. (ed.), Geology and History of Turkey. - Tripoli. 
Casper, S. J. 1974: Plantaginaceae. - Pp 559-608 in: Hartl, D. \& Wagenitz, G. (eds) Hegi G, Illustrierte Flora von Mittel-Europa 6, Teil 1, 2. - Aufl. München.

Davis, P. H. 1949: Additamenta ad floram Anatoliae, I. - Kew Bull. 4: 393-426.

- 1955: Turkish itineraries. - Notes Roy. Bot. Gard. Edinburgh 22: 1-7.

- (ed.) 1965-1985: Flora of Turkey and the East Aegean Islands 1-9. 1965 (vol. 1); 1967 (2); 1970 (3); 1972 (4); 1975 (5); 1978 (6); 1982 (7); 1984 (8); 1985 (9). - Edinburgh.

- Mill, R. R. \& Kit Tan (eds) 1988: Flora of Turkey and the East Aegean Islands, 10 [Suppl. 1]. - Edinburgh.

Dierschke, H. 1994: Pflanzensoziologie. - Stuttgart.

Dierßen, K. 1990: Einführung in die Pflanzensoziologie (Vegetationskunde). - Darmstadt.

Ellenberg, H. \& Mueller-Dombois, D. 1967: A key to Raunkiaer plant life forms with revised subdivisions. - Ber Geobot Inst ETH, Stiftg Rübel, Zürich 37: 56-73.

Eren, Ö., Gökçeoğlu, M. \& Parolly, G. 2004: The flora and vegetation of Bakırlı Dağı (Western Taurus Mts, Turkey), including annotations on critical taxa of the Taurus range. Willdenowia 34: 463-503. https://doi.org/10.3372/wi.34.34212

European Commission, DG Environment 2007: Interpretation Manual of the European Union Habitats EUR25. - Brussels.

Frey, W. \& Lösch, R. 2004: Lehrbuch der Geobotanik, 2. - München.

Gemici, Y. \& Görk, G. 1995: Syntaxonomic position of high mountain vegetation in West and South Anatolia. - 4th Plant Life of SW Asia Symposium, Programme \& Abstracts: 121122.

Güner, A. (ed.) 2012: Türkiye Bitkileri Listesi (Damarlı Bitkiler). - İstanbul.

—, Özhatay, N., Ekim, T. \& Başer, K. H. C. (eds) 2000: Flora of Turkey and the East Aegean Islands, 11 [Suppl. 2]. - Edinburgh.

Hartvig, P. \& Strid, A. 1987: New taxa and new records from the mountains of SW and SC Turkey. - Bot. Jahrb. Syst. 108: 301-341.

Hein, P., Kürschner, H. \& Parolly, G. 1998: Phytosociological studies on high mountain plant communities of the Taurus mountains (Turkey). 2. Rock communities. - Phytocoenologia 28: 465-563. https://doi.org/10.1127/phyto/28/1998/465

Heller, D. \& Heyn, C. C. 1986-1994: Conspectus Florae Orientalis. An Annotated Catalogue of the Flora of the Middle East 3-9. 1986 (vol. 3) Pyrolaceae to Lamiaceae; 1987 (4) Solanaceae to Dipsacaceae; 1990 (5) Mimosaceae to Podostemaceae; 1991 (6) Alismataceae to Orchidaceae; 1993a (7) Cornaceae to Umbelliferae (Apiaceae); 1993b (8) Campanulaceae to Compositae; 1994 (9) Lycopodiaceae to Droseraceae. - Jerusalem.

Jahn, R, \& Schönfelder, P. 1995: Exkursionsflora für Kreta. - Stuttgart.

Karlén, T. 1987: Muscari sandrasicum (Liliaceae), a new species from Turkey. - Willdenowia 16: $375-382$

Kruckeberg, A. R., Adigüzel, N. \& Reeves, R. D. 1999: Glimpses of the flora and ecology of Turkish (Anatolian) serpentines. - Karaca Arboretum Mag. 5(2): 67-86.

Kürschner, H. 1982: Vegetation und Flora der Hochregionen der Aladaglari und Erciyes Dagi, Türkei. Beih Tübinger Atlas Vorderer Orient (TAVO), Reihe A (Naturwiss.) 10. Wiesbaden.

- 1984: Der östliche Orta Toroslar (Mittlerer Taurus) und angrenzende Gebiete. Eine formationskundliche Darstellung der Vegetation Südost-Anatoliens. Beih Tübinger Atlas Vorderer Orient (TAVO), Reihe A (Naturwiss.), 15. - Wiesbaden.

-, Parolly, G. 2012: The Central Anatolian Steppe. - Pp. 149-171 in: Werger, M. J. A. \& van Staalduinen, M. A. (eds) Eurasian Steppes. Ecological Problems and Livelihoods in a Changing World. Plant and Vegetation, 6. 
—, — \& Raab-Straube, E. von 1998: Phytosociological studies on high mountain plant communities of the Taurus Mountains (Turkey). 3. Snow-patch and meltwater communities. - Feddes Repert. 109: 581-616. https://doi.org/10.1002/fedr.19981090714

Kupicha, F. K. 1975: Leontodon L. - Pp. 671-678 in: Davis, P. H. (ed.) Flora of Turkey and the East Aegean Islands, 5. - Edinburgh.

Meikle, R. D. 1977: Flora of Cyprus, 1-2. 1977 (vol. 1); 1985 (2). - Kew.

Mill, R. R. 1982: Lamium L. - Pp. 126-148 in: Davis, P. H. (ed.) Flora of Turkey and the East Aegean Islands, 7. - Edinburgh.

Müller-Schneider, P. 1983: Verbreitungsbiologie (Diasporologie) der Blütenpflanzen. 3 Aufl. Veröff. Geobot. Inst. ETH, Stftg. Rübel, Zürich 61: 1-226.

- 1986: Verbreitungsbiologie der Blütenpflanzen Graubündens. - Veröff. Geobot. Inst. ETH, Stftg. Rübel, Zürich 85: 1-63.

Özhatay, E. 1981: Sandras Dağı'nın (Muğla) Florası ve bazı endemik türleri üzerinde palinolojik ve sitolojik araştırmalar. - İstanbul (Doçentlik tezi).

- 1987: Studia ad Floram Turcicam: New floristic records from Sandras Dağ1 $\left(C_{2}\right.$ Muğla). İstanbul Üniv. Fen. Fak. Mec. B 9: 47-67.

- 1993: Some endemic species of Sandras Dağ1 (C2 Muğla) in Southwest Turkey. - Pp. 725736 in: Demiriz, H. \& Özhatay, N. (eds) Proceedings of the 5. OPTIMA Meeting. İstanbul.

—, Byfield, A. \& Atay, S. 2003: Türkiye'nin Önemli Bitki Alanlar1. - İstanbul.

Öztürk, M., Gemici, Y., Görk, G. \& Seçmen, Ö. 1991: A general account of high mountain flora and vegetation of Mediterranean part of Turkiye. - J. Fac. Sci. Ege. Univ., Ser. B, 13: 5159.

Parolly, G. 1995: Die Steinschuttfluren (Heldreichietea) des Westlichen und Mittleren Taurus (Türkei). Pflanzensoziologische, floristische und ökologische Untersuchungen. - Diss. Bot. 247: 1-374.

- 1998: Phytosociological studies on high mountain plant communities of the South Anatolian Taurus mountains. 1. Scree plant communities (Heldreichietea): A Synopsis. Phytocoenologia 28: 233-284. https://doi.org/10.1127/phyto/28/1998/233

- 2004: The high mountain vegetation of Turkey. A state of the art report, including a first annotated conspectus of the major syntaxa. - Turk. J. Bot. 28: 39-63.

— \& Eren, Ö. 2006: Barbarea brachycarpa Boiss. - Pp. 826-832 in: Parolly, G. \& Eren, Ö. (eds) Contributions to the flora of Turkey, 1. - Willdenowia 36.

—\&- (eds) 2006: Contributions to the flora of Turkey, 1. - Willdenowia 36: 823-844.

— \& - 2007: Colchicum figlalii (Ö. Varol) Parolly \& Eren, comb. nov. - In: Parolly, G. \& Eren, Ö. (eds) Contributions to the flora of Turkey, 2. - Willdenowia 37: 267.

— \& - (eds) 2007: Contributions to the flora of Turkey, 2. - Willdenowia 37: 243-271.

— \& Kit Tan 2006: A new species of Hesperis (Brassicaceae) from SW Anatolia, Turkey. Willdenowia 36: 851-856.

— \& Scholz, H. 2004: Oreopoa gen. novum, two other new grasses and further remarkable records from Turkey. - Willdenowia 34: 145-158.

—, Erdağ, A. \& Nordt, B. 2007: Teucrium (sect. Teucrium) pseudaroanium Parolly, Erdağ \& Nordt, sp. nov. - In: Parolly, G. \& Eren, Ö. (eds) Contributions to the flora of Turkey, 2. - Willdenowia 37: 252-258. https://doi.org/10.3372/wi.37.37114

Pijl, L. van 1982: Principles of dispersal in higher plants, 3rd ed. - Berlin, New York.

Quézel, P. 1973: Contribution à l'étude phytosociologique du massif du Taurus. Phytocoenologia 1: 131-222. https://doi.org/10.1127/phyto/1/1973/131

—, Barbero, M. \& Akman, Y. 1992: Typification de syntaxa décrits en région médterranéenne orientale. - Ecol. Medit. 18: 81-87. https://doi.org/10.3406/ecmed.1992.1708 
Raunkiaer, C. 1934: The life forms of plants and statistical plant geography. - Oxford.

Reeves, R. D. \& Adigüzel, N. 2004: Rare plants and nickel accumulators from Turkish serpentine soils, with special reference to Centaurea species. - Turk. J. Bot. 28: 147-153.

Reichelt, G. \& Wilmanns, O. 1973: Vegetationsgeographie. - Braunschweig.

Şenel, M. 1991: Paleocene-Eocene sediments interbedded with volcanics within the Lycian Nappes: Faralya Formation. - Mineral Res. Exp. Bull. 113: 1-14.

Strid, A. \&, Kit Tan (eds) 1997-2002: Flora Hellenica, 1-2. 1997 (vol. 1); 2002(2). Königstein (1); Rugell (2).

Varol, Ö. 2005: Merendera figlalii (Colchicaceae), a new species from Southwestern Anatolia, Turkey. - Belg. J. Bot. 138(1): 89-92.

Vural, M., Duman, H., Güner, A., Dönmez, A. A. \& Şağban, H. 1995: The vegetation of Köyceğiz-Dalyan (Muğla) Specially Protected Area. - Turk. J. Bot. 19: 431-476.

Weber, H. E., Moravec, J. \& Theurillat, J. P. 2000: International Code of Phytosociological Nomenclature. 3rd ed. - J. Veg. Sci. 11: 739-768. https://doi.org/10.2307/3236580

Zohary, M. 1966: Flora Palaestina 1-2. 1966 (vol. 1) Equisetaceae to Moringaceae; 1972(2) Platanaceae to Umbelliferae. - Jerusalem.

- 1973: Geobotanical Foundations in the Middle East, 1-2. - Stuttgart.

-, Heyn, C. C. \& Heller, D. 1980-1983: Conspectus Florae Orientalis. An Annotated Catalogue of the Flora of the Middle East, 1-2. 1980 (vol. 1) Papaveraceae to Neuradaceae; (2) Oxalidaceae to Hippuridaceae. - Jerusalem.

\section{Unpublished sources}

Gemici, Y,, Görk, G. \& Acar, İ. 1994: Batı ve Güney Anadolu Yüksek Dağ Vejetasyonu ve Florası. I. Vejetasyon (High mountain vegetation and flora of the West and South Anatolia). I. Vegetation. Proje No: TBAG-993. - Ankara.

Tolimir, D. 2001: Pflanzensoziologische Untersuchungen an subalpinen Dornpolster- und Grasfluren im Westlichen und westlichen Mittleren Taurus (Türkei). - Diplomarbeit FU Berlin.

Address of the author:

Gerald Parolly,

Freie Universität Berlin, ZE Botanischer Garten und Botanisches Museum BerlinDahlem, Königin-Luise-Str. 6-8, D-14195 Berlin. Email: G.Parolly@bgbm.org 


\section{APPENDICES}

Appendix 1. Life forms, chorotypes and dispersal of the taxa recorded from the relevés of Sandras Dağı. An exclamation mark in square brackets [!] indicates confirming own field observations of dispersal, a "L" $[\mathrm{L}]$ refers to confirming literature. For general sources of data, see Material and Methods. [Abbreviations: Life forms: Ch frut acanth tragacanthic (fruticose) chamaephyte (thorn-cushion), Ch frut fruticose chamaephyte, $\mathbf{C h}$ frut rept creeping fruticose chamaephyte, $\mathbf{C h}$ herb herbaceous chamaephyte, $\mathbf{C h}$ herb rept creeping herbaceous chamaephyte, $\mathbf{C h}$ pulv pulvinate chamaephyte, $\mathbf{C h}$ succ succulent chamaephyte, $\mathrm{Ch}$ suffr rept creeping suffruticose chamaephyte, Ch suffr suffruticose chamaephyte, $\mathbf{G}$ bulb bulbous geophyte, $\mathbf{G}$ bulb par parasitic bulbous geophyte, $\mathbf{G}$ rhiz rhizomatous geophyte, $\mathbf{H}$ caesp cespitose hemicryptophyte, $\mathbf{H}$ ros rosulate hemicryptophyte, $\mathbf{H}$ scap scapose hemicryptophyte, H sem semirosulate hemicryptophyte, NP nanophanerophyte, T scap hpar hemiparasitic scapose therophyte, T sem semirosulate therophyte. - Chorotypes: EMed East Mediterranean, End Anatol Anatolian endemic, End Anatol (W) Anatolian endemic (western part of Turkey / W of Anatolian Diagonale), End bt Western Taurus (Batı Toroslar) endemic, End loc local endemic, End t Taurus endemic, ES Euro-Siberian, Eux Euxine, IA Irano-Anatolian, IT IranoTuranian, Med Mediterranean, Pont Pontic, subcos Subcosmopolitan, tri triregional (ES-IA-Med). Dispersal types: acanth acanthochory, ball ball(aut)ochory, blast blast(aut)ochory, bole boleochory, cycl cyclochory, dysz dyszoochory, ela elaisomochory, herp herpochory, hydro (ombro)hydrochory, loph lophochory, myx myxochory, pogo pogonochory, pter pterochory, sarc sarcochory].

\begin{tabular}{|c|c|c|c|}
\hline Taxon & Life form & Chorotype & Dispersal type \\
\hline $\begin{array}{l}\text { Acantholimon ulicinum (Willd. ex Schult.) Boiss. var. purpu- } \\
\text { rascens (Bokhari) Bokhari \& J. R. Edm. }\end{array}$ & Ch frut acanth & End Anatol & pter \\
\hline $\begin{array}{l}\text { Aethionema cordatum (Desf.) Boiss. subsp. pichleri (Boiss.) } \\
\text { Hartvig \& Strid }\end{array}$ & H scap (G rhiz?) & End Anatol & hydro \\
\hline $\begin{array}{l}\text { Aethionema speciosum Boiss. \& Huet subsp. compactum } \\
\text { Hartvig \& Strid }\end{array}$ & Ch pulv & End loc & hydro \\
\hline Allium sp. (sterile) & G bulb & - & bole \\
\hline Alopecurus gerardii Vill. & H caesp & (E)Med & acanth (dysz) \\
\hline Alyssum propinquum Baumgartner & Ch suffr rept & End Anatol & hydro \\
\hline $\begin{array}{l}\text { Anthemis cretica L. subsp. cretica [incl. subsp. leucanthe- } \\
\text { moides (Boiss.) Griers.] }\end{array}$ & Ch suffr & EMed & bole (dysz) \\
\hline Arenaria ledebouriana Fenzl var. ledebouriana & Ch pulv / Ch suffr rept & End Anatol & bole \\
\hline Asperula stricta Boiss. subsp. monticola Ehrend. & Ch suffr (rept) & End $t$ & bole \\
\hline Astragalus angustifolius Lam. var. violaceus Boiss. & Ch frut acanth & EMed & ball [!] \\
\hline Astragalus condensatus Ledeb. & Ch frut acanth & End Anatol & ball \\
\hline $\begin{array}{l}\text { Asyneuma virgatum (Labill.) Bornm. subsp. cichoriiforme } \\
\text { (Boiss.) Damboldt }\end{array}$ & H sem & End Anatol & bole \\
\hline $\begin{array}{l}\text { Barbarea brachycarpa Boiss. subsp. anfractuosa (Hartvig \& } \\
\text { Strid) Parolly \& Eren }\end{array}$ & H caesp & End loc & bole \\
\hline $\begin{array}{l}\text { Bolanthus frankenioides (Boiss.) Barkoudah var. fasciculatus } \\
\text { (Boiss. \& Heldr.) Barkoudah }\end{array}$ & Ch suffr rept & End bt & bole \\
\hline
\end{tabular}




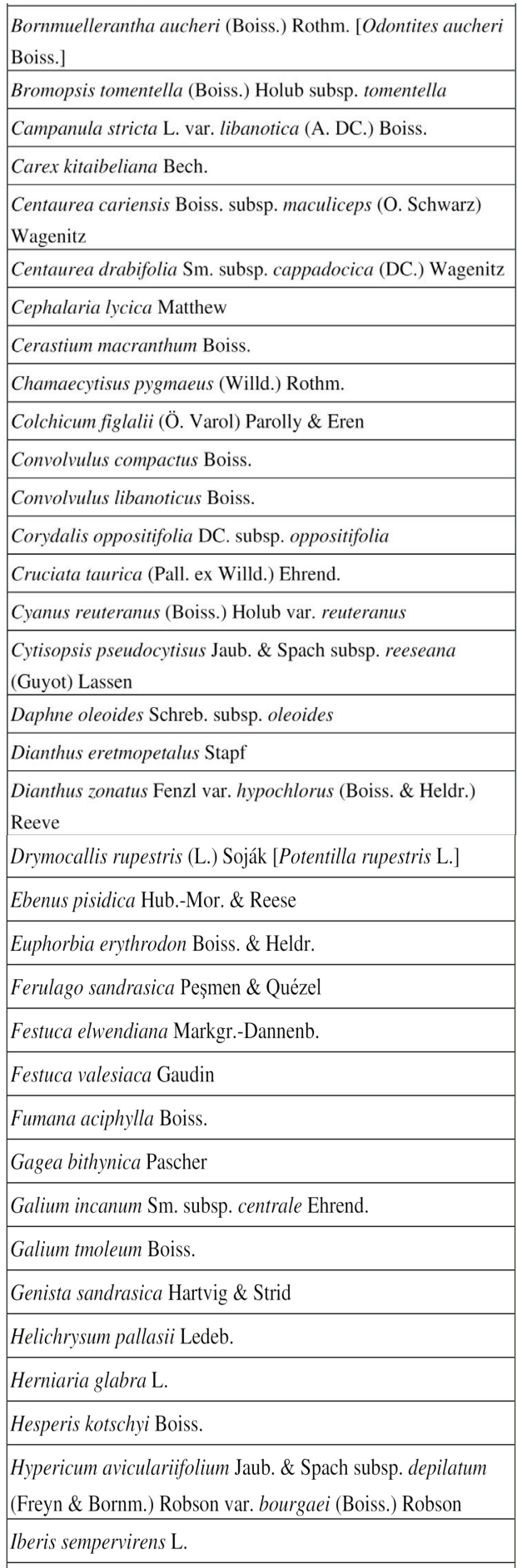

\begin{tabular}{|c|c|c|}
\hline T scap hpar & IA & bole \\
\hline H caesp & EMed-IA & pter (dysz) \\
\hline H scap / Ch suffr & EMed & bole \\
\hline H caesp & (E)Med & acanth [!] \\
\hline H sem & End. bt s.l. & bole / ela \\
\hline Ch pulv & End Anatol & cycl (ela) [!] \\
\hline Ch suffr & End bt & acanth \\
\hline H caesp & End $\mathrm{t}$ & bole \\
\hline Ch suffr rept & ES-EMed & ball \\
\hline G bulb & End loc & ela [!] \\
\hline Ch pulv & EMed-IA & bole \\
\hline Ch suffr & EMed & bole \\
\hline G bulb & EMed-IA & ball / ela \\
\hline Ch suffr & EMed & bole \\
\hline $\mathrm{H}$ caesp / H ros & End bt & $\operatorname{cycl}(\mathrm{ela})[!]$ \\
\hline Ch suffr rept & EMed & cycl [!] \\
\hline Ch frut (NP) & EMed-IA & sarc [!] \\
\hline Ch pulv / Ch suffr & End bt & bole \\
\hline Ch pulv / Ch suffr rept & EMed & bole \\
\hline Ch suffr & EMed-IA & bole [L] \\
\hline Ch suffr rept & End loc s.l. & cycl [!] \\
\hline Ch suffr rept & End Anatol (W) & blast / ela \\
\hline H sem & End t & pter (dysz) \\
\hline H caesp & IA & pter (dysz) \\
\hline H caesp & tri & pter (dysz) [L] \\
\hline Ch suffr & IA & bole / myx [L] \\
\hline G bulb & ES-EMed & blast / ela [!] \\
\hline Ch suffr & End $t$ & bole \\
\hline Ch herb & End bt & bole \\
\hline Ch suffr rept & End loc & ball \\
\hline Ch pulv / Ch suffr rept & IA & pogo \\
\hline Ch herb rept & subcos & cyclo $[\mathrm{L}]$ \\
\hline H sem & End t & bole \\
\hline Ch suffr & End t & bole \\
\hline Ch suffr & E(Med) & hydro [L] \\
\hline
\end{tabular}




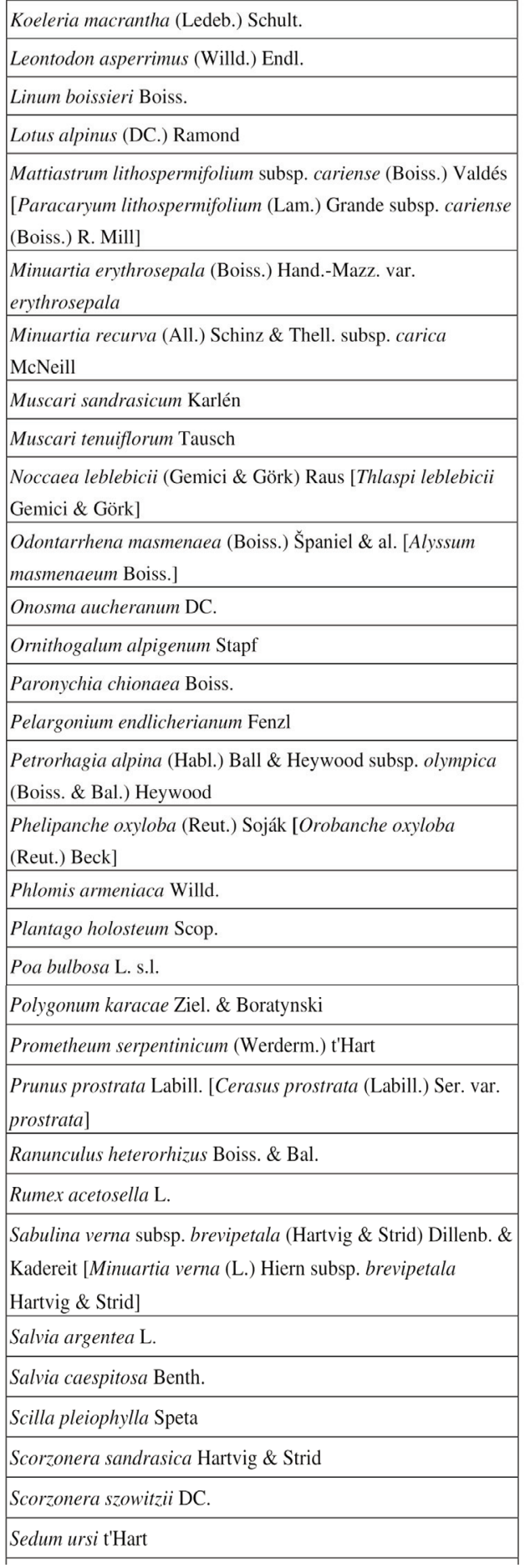

\begin{tabular}{|c|c|c|}
\hline H caesp & tri & pter (dysz) [L] \\
\hline H ros & IA & pogo \\
\hline Ch suffr & End Anatol & myx \\
\hline Ch herb & tri (ES) & ball [!] \\
\hline H caesp & EMed & pter / acanth [!] \\
\hline Ch herb rept / Ch pulv & End Anatol & cycl [!] \\
\hline Ch pulv & End loc & bole \\
\hline G bulb & End loc & hydro \\
\hline G bulb & tri (EMed-IA?) & hydro \\
\hline Ch pulv & End loc & hydro \\
\hline Ch suffr & End Anatol & bole \\
\hline Ch suffr & EMed & bole \\
\hline G bulb & End $t$ & blast / ela [!] \\
\hline Ch pulv / Ch suffr rept & EMed-Pont & $\operatorname{cycl}[!]$ \\
\hline G rhiz & EMed-IA & ball / herp [!] \\
\hline T sem & EMed-ES & bole \\
\hline G bulb par & EMed-IA & bole \\
\hline Ch suffr & End Anatol & bole \\
\hline Ch pulv / $\mathrm{H}$ ros & Med & myx [!] \\
\hline G bulb (H caesp) & tri & acanth (dysz) [L] \\
\hline Ch suffr & End t & bole \\
\hline Ch succ & End loc & hydro \\
\hline Ch frut rept & Med & $\operatorname{sarc}[!]$ \\
\hline G bulb & End Anatol (W) & bole \\
\hline T sem & subcos & pter [L] \\
\hline Ch suffr rept & End bt & bole $[\mathrm{L}]$ \\
\hline H sem & Med & bole / myx \\
\hline Ch pulv / Ch suffr rept & End Anatol & bole / myx [!] \\
\hline G bulb & End (b)t & blast / ela [!] \\
\hline H ros / Ch pulv & End loc & pogo [!] \\
\hline H ros & IA & pogo [!] \\
\hline Ch succ & End Anatol & hydro \\
\hline
\end{tabular}




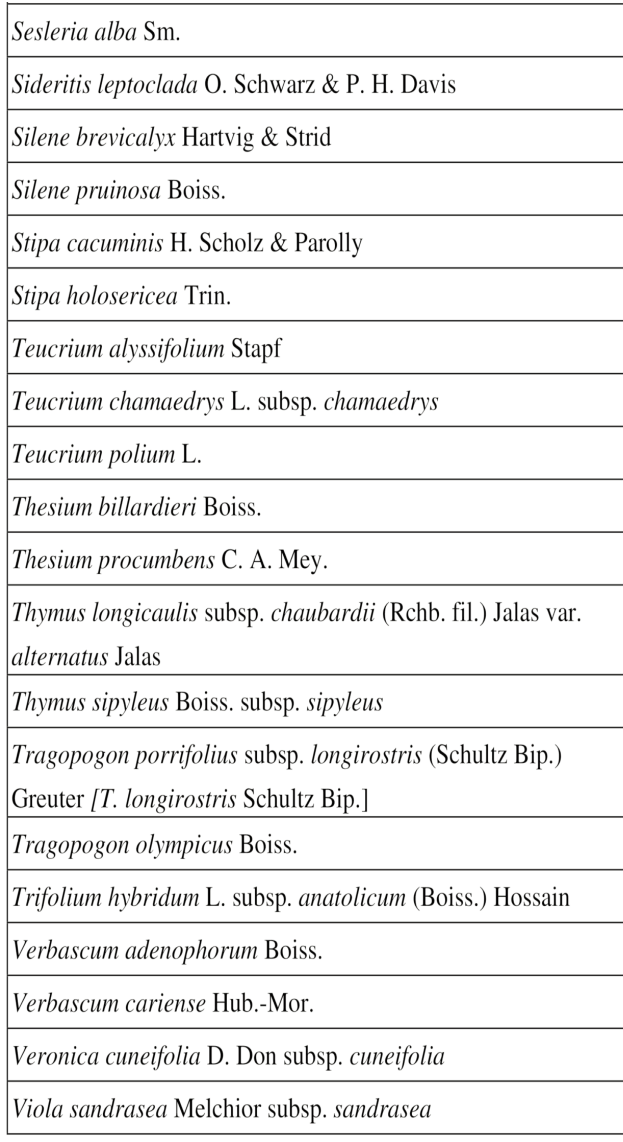

\begin{tabular}{|c|c|c|}
\hline H caesp & End Anatol & pter (dysz) \\
\hline Ch suffr & End loc s.l. & bole \\
\hline Ch suffr & End loc & bole \\
\hline Ch suffr & IA (-ES) & bole \\
\hline H caesp & End $t$ & loph / herp [!] \\
\hline H caesp & IA & loph / herp \\
\hline Ch suffr & End bt & bole \\
\hline Ch suffr & ES-Med & bole [L] \\
\hline Ch suffr & Med & bole \\
\hline Ch suffr rept & IA & ela \\
\hline Ch suffr rept & EMed-Eux & blast / ela \\
\hline Ch suffr rept & End Anatol & bole (myx) \\
\hline Ch frut rept & End Anatol & bole (myx) \\
\hline H sem & EMed-IA & pogo \\
\hline H scap & End Anatol & pogo [!] \\
\hline H caesp & EMed-IA & blast [!] \\
\hline $\mathrm{H}$ ros & End loc s.l. & bole \\
\hline H ros & End loc s.l. & bole \\
\hline Ch suffr rept & End $t$ & bole \\
\hline $\mathrm{H}$ ros & End loc s.l. & blast / ela \\
\hline
\end{tabular}


Appendix 2. Annotated list of sampling localities (plots) on Sandras Dağ above Ağla (see Fig. 2, Table 1-3). Note that the localities shown in Fig. 2 have been numbered from left to right, while the localities and plots are chronologically arranged [relevés established by D Döring \& Parolly; T Tolimir \& Parolly; 1-25 present author].

\begin{tabular}{|c|c|c|}
\hline $\begin{array}{l}\text { Plot / } \\
\text { relevé no. }\end{array}$ & $\begin{array}{c}\text { Locality } \\
\text { no. }\end{array}$ & Locality, plot annotation and sampling date \\
\hline $\begin{array}{c}\text { 1-5, T1- } \\
\text { T2 }\end{array}$ & 7 & $\begin{array}{l}\text { Altınsivri, summit plateau and adjoining rocky inclines, } 2100-2190 \mathrm{~m} \text {, } \\
20.6 .1999\end{array}$ \\
\hline 1 & & $\begin{array}{l}\text { Summit community (Gipfelflur); boulders of compact peridotite to } 50 \text { × } 50 \text { × } 50 \\
\mathrm{~cm}^{3} \text {, densely covered by Rhizocarpum geographicum; stands up to } 30 \mathrm{~cm} \text { high, } \\
\text { mainly in the shelter of stones; reddish ophiolitic fine soil. }\end{array}$ \\
\hline 2 & & $\begin{array}{l}\text { Rocky, stabilised slope with gentle steps and boulders; stands dominated by ca. } 5 \\
\mathrm{~cm} \text { low shrublets of Cytisopsis pseudocytisus and taller tufts of Poa bulbosa ( } 20 \\
\mathrm{~cm} \text { high). }\end{array}$ \\
\hline $3 \& 4$ & & As 2 , but more turf-like. \\
\hline 5 & & $\begin{array}{l}\text { Summit community (Gipfelflur) at the margin of the plateau, few large rocks, } \\
\text { structurally similar to plot } 1 \text {. }\end{array}$ \\
\hline $\mathrm{T} 1-\mathrm{T} 2$ & & $\begin{array}{l}\text { Rock-strewn flats and gentle slope close to the summit plateau, with changing } \\
\text { proportions of fine soil visible at the surface. }\end{array}$ \\
\hline 6, T3-T4 & 8 & $\begin{array}{l}\text { Altınsivri, eastern flank (above the saddle between Çiçekbaba Tepesi and } \\
\text { Altmsivri), } 2000 \mathrm{~m}, \mathbf{2 0 . 6 . 1 9 9 9}\end{array}$ \\
\hline 6 & & Rocky, stepped slope with swards and m-high boulders. \\
\hline $\mathrm{T} 3$ & & $\begin{array}{l}\text { Steep and rocky slope at the foot of large rock, stepped; xerophytic sward with } \\
\text { Stipa cacuminis and Salvia argentea as tallest plants. }\end{array}$ \\
\hline $\mathrm{T} 4$ & & $\begin{array}{l}\text { Next to plot T3, but only moderately sloping, vegetation more mesophytic and } \\
\text { turf-like; with a better water-supply, abundant fine soil. }\end{array}$ \\
\hline $7-13$, D1 & 4 & $\begin{array}{l}\text { Ciçekbaba Tepesi, ascent from Çiral, valley } \mathrm{E} \text { of the main summit, } \\
37^{\circ} 04{ }^{\prime} 82^{\prime}{ }^{\prime}, 028^{\circ} 49^{\prime} 91^{\prime} ' \mathrm{E}, 1900-2180 \mathrm{~m} \text {, valley bottom and adjoining grazed } \\
\text { slopes, 21.6.1999 }\end{array}$ \\
\hline 7 & & $\begin{array}{l}\text { Valley bottom with snow-beds close to late hanging snow, boulders to } 50 \times 30 \\
\mathrm{~cm}^{2} \text {, abundant fine soil, no scree. }\end{array}$ \\
\hline 8 & & $\begin{array}{l}\text { As in } 7 \text {, but with smaller boulders than in previous plot; fine-soil layer thin, } \\
\text { relatively compressed, thus surface less denudated than in plot } 7 \text { (only a few } \mathrm{cm}^{2} \\
\text { of open soil present). }\end{array}$ \\
\hline 9 & & As in 8 , but stones only $15 \times 15 \times 10 \mathrm{~cm}^{3}$. \\
\hline $10,12-13$ & & $\begin{array}{l}\text { Lower gentle slope with }( \pm \text { ) dense carpet turf (snow-beds) ca. } 10-50 \mathrm{~m} \text { above the } \\
\text { valley bottom; stands stronger browsed than those of the previous plots. }\end{array}$ \\
\hline 11 & & Valley bottom with browsed, dense snow-beds, $2100 \mathrm{~m}$. \\
\hline D1 & & $\begin{array}{l}\text { Lateral ridge of valley, steep slope ca. } 50-60 \mathrm{~m} \text { above the valley bottom, with open } \\
\text { mesophytic dwarf-shrub community and much bare soil. }\end{array}$ \\
\hline D2-5 & 3 & Çiçekbaba Tepesi, eastern slope below the main summit, 21.6.1999 \\
\hline D2 & & Steep, stepped and rocky slope close to meltwater runnels. \\
\hline D3-5 & & $\begin{array}{l}\text { Flat area (= a step of the rocky, boulder-rich slope) below the last ascent to the } \\
\text { summit. }\end{array}$ \\
\hline 14-19 & 1 & Çiçekbaba Tepesi, summit plateau, 21.6.1999 \\
\hline $14 \& 15$ & & Fixed coarse scree to block scree. \\
\hline
\end{tabular}




\begin{tabular}{|c|c|c|}
\hline $16 \& 17$ & & Stony, almost flat wind-swept hill top. \\
\hline \multirow[t]{2}{*}{18} & & Hill top lateral (E) of main summit, surrounded by block-scree with various \\
\hline & & proportions of finer material. \\
\hline \multicolumn{2}{|l|}{19} & Slope with stabilised boulder scree, tentatively poor in fine soil. \\
\hline $20 \mathrm{a} \& \mathrm{~b}$ & 2 & $\begin{array}{l}\text { Çiçekbaba Tepesi, } \mathrm{N} \text {-facing slope, } 50-120 \mathrm{~m} \text { below the summit plateau, } \\
\text { 21.6.1999 }\end{array}$ \\
\hline \multirow[t]{2}{*}{$20 \mathrm{a}$} & & High-covering meltwater vegetation ca. $8 \mathrm{~m}$ from a large snow-field; plot divided \\
\hline & & by a $50-70 \mathrm{~cm}$ wide meltwater runnel with trickling water; few rocks. \\
\hline $20 \mathrm{~b}$ & & As in 12 , but closer to the snow and much stronger flow of meltwater. \\
\hline \multirow[t]{4}{*}{$21-23$} & 6 & Çiralı below Altınsivri, $37^{\circ} 03^{\prime} \mathrm{N}, 028^{\circ} 48^{\prime} \mathrm{E}$, flat alluvial plain with gravel and \\
\hline & & fine soil-rich ultramafic soil, supporting sites similarto those of meltwater \\
\hline & & vegetation, sampled vegetation confined to runnels and small depressions, \\
\hline & & 22.6.1999 \\
\hline 21 & & Doline-like depression; stands ca. $20 \mathrm{~cm}$ high (Odontarrhena masmenaea). \\
\hline 22 & & Stony runnel; stands ca. $20 \mathrm{~cm}$ high (Odontarrhena masmenaea). \\
\hline \multirow[t]{3}{*}{23} & & Surface gravely; densely packed gravel and debris (mostly $<10 \mathrm{~cm}$ ), small \\
\hline & & amounts of fine soil; stands on average very low (ca. $3 \mathrm{~cm}$ high, Linum boissieri, \\
\hline & & over-topped by Poa bulbosa, etc.). \\
\hline \multirow[t]{2}{*}{$24-25$} & 5 & Akköprü Çögenli [= saddle between Altınsivri and Çiçekbaba Tepesi], \\
\hline & & 22.6.1999. \\
\hline \multirow[t]{2}{*}{24} & & Rocky wind-exposed slope with boulders, coarse- and fine-scree, compact \\
\hline & & peridotite. \\
\hline 25 & & Gentle scree slope with medium-sized stones and a few boulders. \\
\hline
\end{tabular}

